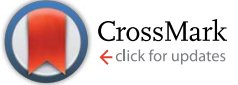

Cite this: Chem. Sci., 2016, 7, 995

\title{
Base pairing involving artificial bases in vitro and in vivo†
}

\author{
Omprakash Bande, $\dot{t}^{\mathrm{b}}$ Darren Braddick, $\dot{t}^{\mathrm{a}}$ Stefano Agnello, $\dot{t}^{\mathrm{b}}$ Miyeon Jang, ${ }^{\mathrm{b}}$ \\ Valérie Pezo, ${ }^{a}$ Guy Schepers, ${ }^{\mathrm{b}}$ Jef Rozenski, ${ }^{\mathrm{b}}$ Eveline Lescrinier, ${ }^{\mathrm{b}}$ Philippe Marlière ${ }^{\mathrm{a}}$ \\ and Piet Herdewijn ${ }^{\star a b}$
}

Herein we report the synthesis of $N^{8}$-glycosylated 8-aza-deoxyguanosine ( $N^{8}$-8-aza-dG) and 8-aza-9deaza-deoxyguanosine $\left(N^{8}-8\right.$-aza-9-deaza-dG) nucleotides and their base pairing properties with 5 methyl-isocytosine ( $d$-iso $\mathrm{C}^{\mathrm{Me}}$ ), 8-amino-deoxyinosine (8- $\mathrm{NH}_{2}$ - $\mathrm{dl}$ ), 1- $\mathrm{N}$-methyl-8-amino-deoxyinosine (1-Me-8- $\mathrm{NH}_{2}$-dl), 7,8-dihydro-8-oxo-deoxyinosine (8-Oxo-dl), 7,8-dihydro-8-oxo-deoxyadenosine (8Oxo-dA), and 7,8-dihydro-8-oxo-deoxyguanosine (8-Oxo-dG), in comparison with the d-isoC ${ }^{\mathrm{Me}}: \mathrm{d}$-isoG artificial genetic system. As demonstrated by $T_{m}$ measurements, the $N^{8}-8$-aza-dG:d-isoC ${ }^{M e}$ base pair formed less stable duplexes as the $\mathrm{C}: \mathrm{G}$ and $\mathrm{d}$-isoC $\mathrm{Ce}^{\mathrm{Me}}: \mathrm{d}$-isoG pairs. Incorporation of $8-\mathrm{NH}_{2}-\mathrm{dl}$ versus the $N^{8}$-8-aza-dG nucleoside resulted in a greater reduction in $T_{m}$ stability, compared to $d$-isoC ${ }^{M e}: d$-isoG. Insertion of the methyl group at the $N^{1}$ position of $8-\mathrm{NH}_{2}$-dl did not affect duplex stability with $N^{8}-8$ aza- $d G$, thus suggesting that the base paring takes place through Hoogsteen base pairing. The cellular interpretation of the nucleosides was studied, whereby a lack of recognition or mispairing of the incorporated nucleotides with the canonical DNA bases indicated the extent of orthogonality in vivo. The most biologically orthogonal nucleosides identified included the 8-amino-deoxyinosines (1-Me-8- $\mathrm{NH}_{2}-$ $\mathrm{dl}$ and $8-\mathrm{NH}_{2}-\mathrm{dl}$ ) and $\mathrm{N}^{8}$-8-aza-9-deaza-dG. The 8-oxo modifications mimic oxidative damage ahead of cancer development, and the impact of the MutM mediated recognition of these 8-oxodeoxynucleosides was studied, finding no significant impact in their in vivo assay.

Received 15th September 2015 Accepted 28th October 2015

DOI: $10.1039 / \mathrm{c} 5 \mathrm{sc} 03474 d$

www.rsc.org/chemicalscience partners is an $N^{8}$ substituted purine base and involving hydrogen-bond formation in the recognition process.

The unnatural isoG:isoC ${ }^{\mathrm{Me}}$ base pair ${ }^{\mathbf{9 1 0}}$ is not adequate to expand the genetic code and has restricted application due to facile tautomerization of isoG which enables it to form base pairs with selected natural nucleobases. Tautomerism leads to promiscuity and heterocycles (via tautomerism) possibly leading to pairing with natural bases, should be avoided when selecting new orthogonal information systems. ${ }^{1}$ Therefore, we would like to replace the isoG base in the isoG:isoC ${ }^{\mathrm{Me}}$ base pair by another heterocycle less prone to tautomerization. In search for new artificial genetic systems efforts have been devoted to the study of $C$-nucleosides ${ }^{11-13}$ and nucleosides with an aberrant glycosidic linkage i.e. with an $N^{8}$ glycosylated nucleobase, ${ }^{14-17}$ as they demonstrate unexpected pairing behavior and some of them may function as universal bases. ${ }^{18,19}$ Seela et al., have demonstrated that altering the glycosylation site of a nucleoside from $N^{9}$ to $N^{8}$ results in a change of the nucleobase recognition pattern, $\quad N^{8}$-glycosylated-7-deaza-8-azaguanine behaves like isoguanine ${ }^{20}$ and forms base pairs with isoC ${ }^{\mathrm{Me}}$ and not with cytosine. Therefore, we have investigated $N^{8}$-glycosylated 8-azaguanine ${ }^{21-23}$ 1a together with its $N^{9}$-deaza-analogue $\mathbf{1 b}$. Removal of the $N^{9}$ nitrogen atom (giving 1b) may have an influence on the in vitro and in vivo recognition of the
Genopole Campus 1, Bât. 6, F-91030 Évry Cedex, France

${ }^{b}$ Medicinal Chemistry, Rega Institute for Medical Research, $K U$ Leuven, Minderbroedersstraat 10, 3000 Leuven, Belgium. E-mail: piet.herdewijn@rega. kuleuven.be; Tel: +32 16337387

$\dagger$ Electronic supplementary information (ESI) available. See DOI: 10.1039/c5sc03474d

\$ Contributed equally to this article. 
$N^{8}$-glycosylated purine nucleoside. Potentially, the $N^{8}$-glycosylated purine nucleoside may be recognized by another purine nucleoside, when Hoogsteen base pairing is involved. To evaluate the potential of involving such Hoogsteen recognition ${ }^{24}$ in an unnatural base pair, 8-amino-hypoxanthine ${ }^{25,26}$ 2a was selected as the pairing partner for the $N^{8}$-glycosylated bases $\left(N^{8}\right.$ 8-aza-dG, $N^{8}$-8-aza-9-deaza-dG) as shown in Fig. 1. For Hoogsteen pairing in a duplex structure, one of the bases should adopt the 'syn' conformation and 8-substituted purines preferentially adopt this conformation. ${ }^{27,28}$ The 1-Me-8- $\mathrm{NH}_{2}$-dI nucleobase $\mathbf{2 b}$ was tested in order to exclude Watson-Crick type recognition in 1a/1b:2a base pairing. Changing the 8-amino group in $\mathbf{2 a}$ in an 8-hydroxy group will, first, abolish recognition by $\mathbf{1 a}$ and $\mathbf{1 b}$, which would be further demolished by changing the aad system of 2 in the $d d a$ system of $\mathbf{5}$ (the $d d a$ system is also present in 1a and 1b) (Fig. 2). Therefore, and to fully understand the base pairing pattern, we have also synthesized and evaluated the 7,8-dihydroxy-8-oxonucleosides with the 6-Oxo ${ }^{29} 3$, 6-Oxo-2amino $^{30-34} 4$ and 6 -amino ${ }^{35-38} 5$ base moieties. Because of the favored syn conformation of 8-hydroxylated purine, Hoogsteen base pairing may be preferred over Watson-Crick base pairing. ${ }^{39-41} \mathrm{~A}$ conclusion is that Watson-Crick type base pairing as well as Hoogsteen type base pairing can be considered when selecting orthogonal base pairs in vitro and in vivo.

In order to determine the orthogonality of the nucleosides against the biological situation, they were individually analyzed in vivo in an XNA-dependent DNA synthesis assay. For these nucleosides the assay studied the pairing properties of each, with an extension of the study performed for the 7,8-dihydro-8oxoguanine and 7,8-dihydro-8-oxoadenine bases in vivo, the former of which is formed by ROS-mediated damage of DNA.42,43 Both of the 8-oxo-deoxynucleoside bases were analyzed in wildtype and knockout backgrounds of the important 8-oxo repair enzyme MutM. ${ }^{\mathbf{4 4 5}}$ The assay was to determine whether or not this enzyme in particular was influencing the base pairing results determined by tests, and confirm that the non-natural nucleosides here were not being chemically modified in vivo, thus affecting the results obtained.
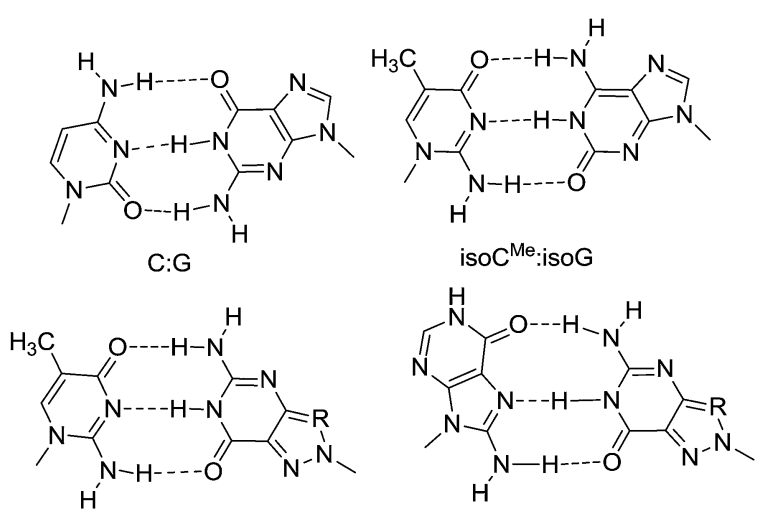

$\mathrm{R}=\mathrm{N}$; isoC $\mathrm{Me}: 8$-aza-G

$\mathrm{R}=\mathrm{N} ; 8-\mathrm{NH}_{2}-\mathrm{Hx}: 8-\mathrm{aza}-\mathrm{G}$ $\mathrm{R}=\mathrm{CH}$; isoC ${ }^{\mathrm{Me}}: 8$-aza-9-deaza-G

$\mathrm{R}=\mathrm{CH} ; 8-\mathrm{NH}_{2}-\mathrm{Hx}: 8-$ aza-9-deaza-G

Fig. 1 Putative base pair motifs of duplexes with antiparallel strand orientation.
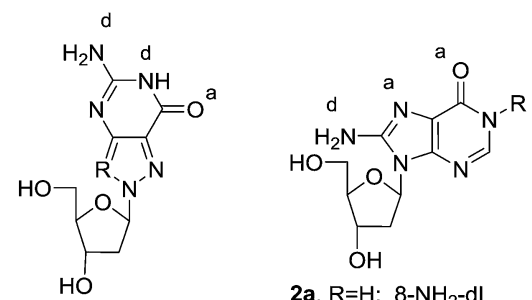

2a, $\mathrm{R}=\mathrm{H} ; 8-\mathrm{NH}_{2}$-dl 1a, R=N; $\mathrm{N}^{8}-8$-aza-dG

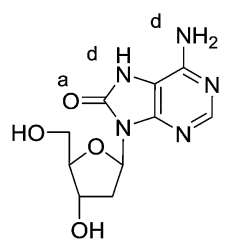

5, 8-Oxo-dA 2b,

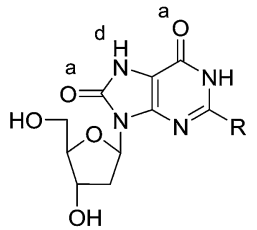

3, $\mathrm{R}=\mathrm{H} ; 8-\mathrm{O} \times \mathrm{o}-\mathrm{dl}$ 4, $\mathrm{R}=\mathrm{NH}_{2} ; 8-\mathrm{O} \times 0-\mathrm{dG}$
Fig. 2 2'-Deoxyribo-nucleosides, with modified purine and pyrimidine bases.

\section{Results and discussion}

\section{Synthesis of monomers}

As depicted in Scheme 1, the $\mathrm{BF}_{3}-\mathrm{Et}_{2} \mathrm{O}$-catalysed glycosylation of commercially available 8 -azaguanine (8) with 1,2,3,5-tetra- $O$ acetyl- $\beta$-D-ribofuranose afforded $\mathbf{9}$ as the major isomer. The assignment of $N^{8}$ glycosidic bond in $\mathbf{9}$ was made by comparing spectral data with the known compound 1a in later stage. The cleavage of the acetyl-protecting group was carried out using ammonium hydroxide at room temperature for 8 hours, obtaining compound 10a in $91 \%$ yield. ${ }^{\mathbf{4 6 , 4 7}}$ The regioselective protection of the $3^{\prime}-\mathrm{OH}$ and $5^{\prime}-\mathrm{OH}$ groups with $\mathrm{TIPDSiCl}_{2}$ gave compound 14a.

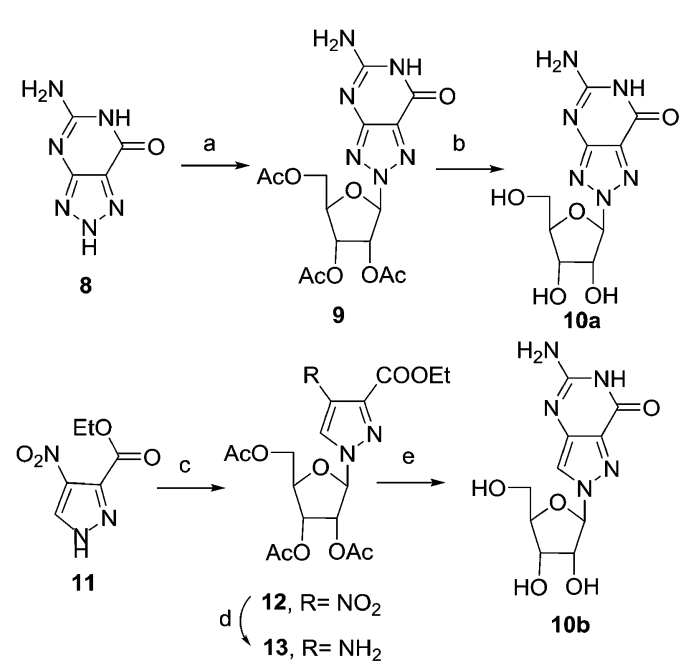

Scheme 1 Synthesis of $N^{8}$-8-aza-G and $N^{8}$-8-aza-9-deaza-G nucleoside. Reagents and conditions: (a) $\mathrm{BF}_{3}-\mathrm{Et}_{2} \mathrm{O}, 1,2,3,5$-tetra-Oacetyl- $\beta$-D-ribofuranose, $\mathrm{CH}_{3} \mathrm{CN}, 75^{\circ} \mathrm{C}, 3 \mathrm{~h}, 54 \%$; (b) $\mathrm{NH}_{4} \mathrm{OH}, \mathrm{rt}, 8 \mathrm{~h}$, 91\%; (c) BSA, DCE, $\mathrm{SnCl}_{4}, 1,2,3,5$-tetra- $O$-acetyl- $\beta$-D-ribofuranose, rt, 36 h, $85 \%$; (d) $\mathrm{H}_{2}, 10 \% \mathrm{Pd} / \mathrm{C}, \mathrm{MeOH}, \mathrm{rt}, 8 \mathrm{~h}, 100 \%$; (e) (i) chloro-formamidine hydrochloride, DMS, $120{ }^{\circ} \mathrm{C}, 1 \mathrm{~h}$, (ii) $\mathrm{NH}_{4} \mathrm{OH}, \mathrm{rt}, 1 \mathrm{~h}, 42 \%$. 
For the deoxygenation of the $\mathrm{C} 2^{\prime}$-hydroxy group, the BartonMcCombie reaction was used. We first converted the nucleoside 14a into the corresponding thiocarbamate, which, after radical reduction in the presence of tributylstannane and AIBN, gave the desired nucleoside 15a (Scheme 2).

Subsequently, the removal of the silyl-protecting group, carried out using TBAF in THF at room temperature for 4 hours, afforded compound 1a to $94 \%$ yield. The spectral and analytical data of 1a were found to be in accordance with reported data. ${ }^{21}$ Protection of the amino group of $\mathbf{1 a}$ followed by the selective protection of the primary alcohol with 4,4'-dimethoxytrityl chloride (DMTrCl) in pyridine, provided the protected nucleoside 17a, ${ }^{21}$ which was then converted into phosphoramidite 18a by reaction with bis(diisopropylamino)(2-cyanoethoxy)phosphine in the presence of tetrazole.

The synthesis of the $N^{8}$-8-aza-9-deaza-dG derivative started from the readily available pyrazole $\mathbf{1 1}$. Vorbrüggen reaction of 11 with 1,2,3,5-tetra- $O$-acetyl- $\beta$-D-ribofuranose, in the presence of $\mathrm{SnCl}_{4}$, afforded the desired $N^{1}$-isomer 12 as the major product (91\% yield). ${ }^{48}$ The reduction of the nitro group of $\mathbf{1 2}$, followed by the ring closure with chloroformamidine hydrochloride and deprotection of acetyl groups in one pot, gave the desired compound 10b (Scheme 1). Analogously to what is described for the $N^{8}$-8-aza-guanine derivatives in Scheme 2, a series of transformations starting from 10b allowed us to obtain the deoxy derivative $\mathbf{1 b}$ and finally the corresponding phosphoramidite $\mathbf{1 8 b}$.

As depicted in Scheme 3, the synthesis of the phosphoramidite of $8-\mathrm{NH}_{2}$-dI (2a) started from the silylated deoxyinosine 19. ${ }^{49}$ The compound 19 was treated with tosyl azide and $n$ butyllithium in anhydrous THF at $-78{ }^{\circ} \mathrm{C}$ for 2 hours yielding

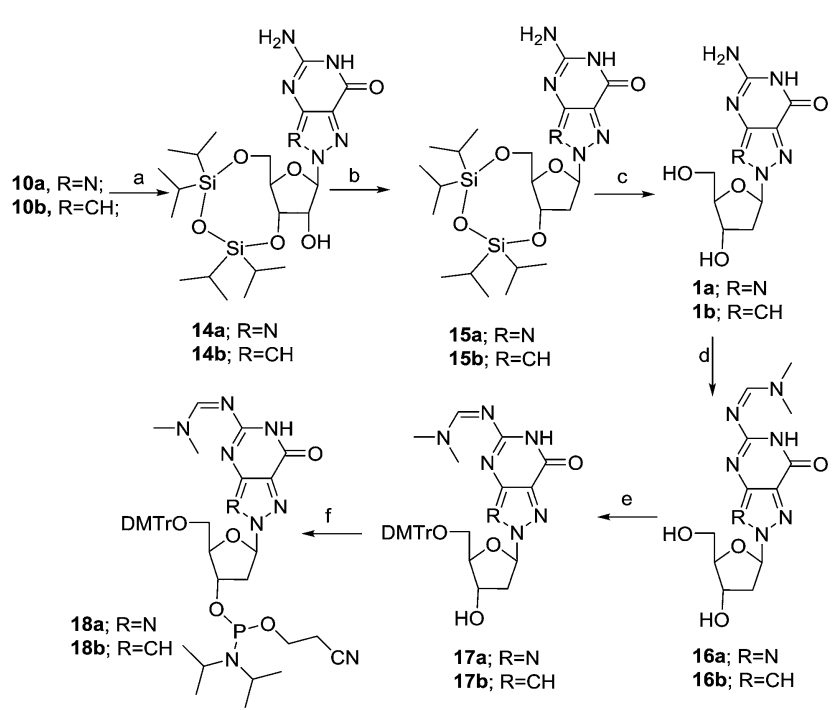

Scheme 2 Synthesis of $N^{8}$-8-aza-dG and $N^{8}$-8-aza-9-deaza-dG nucleoside. Reagents and conditions: (a) TIPDSiCl 2 , pyridine, $0^{\circ} \mathrm{C}$ to rt, $8 \mathrm{~h}, 74-77 \%$; (b) (i) TCDI, $\mathrm{CH}_{2}-\mathrm{Cl}_{2}, \mathrm{rt}, 8 \mathrm{~h}$; (ii) AlBN, $n B u_{3} \mathrm{SnH}$, toluene, $75{ }^{\circ} \mathrm{C}, 2$ h, 62-68\%; (c) TBAF, THF, rt, 4 h, 94-97\%; (d) DMF-DMA, $\mathrm{MeOH}, 50{ }^{\circ} \mathrm{C}, 1 \mathrm{~h}, 93-96 \%$; (e) $\mathrm{DMTrCl}$, pyridine, $0{ }^{\circ} \mathrm{C}$ to rt, $55 \mathrm{~min}, 2 \mathrm{~h}$, 76-83\%; (f) (i- $\left.\mathrm{Pr}_{2} \mathrm{~N}\right)_{2} \mathrm{POCH}{ }_{2} \mathrm{CH}_{2} \mathrm{CN}, 1 \mathrm{H}$-tetrazole, $\mathrm{CH}_{2} \mathrm{Cl}_{2}, \mathrm{O}^{\circ} \mathrm{C}$ to rt, 55 min, 2 h, $69-73 \%$.
$60 \%$ of the protected 8 -azido-dI nucleoside $20 a$. The reduction of the azide group was carried out using sodium borohydride in methanol and further protected with an $N, N$-dimethylamino methylidene residue using dimethylformamide dimethyl acetal in methanol at $70{ }^{\circ} \mathrm{C}$ for 1 hour. The cleavage of the silyl protecting group was carried out using TBAF in THF at room temperature for 12 hours, to obtain compound 22a to $60 \%$ yield. Subsequently, compound 22a was tritylated and phosphitylated, furnishing the phosphoramidite 24a via 23a. For the synthesis of the 1-Me-8- $\mathrm{NH}_{2}$-dI building block, the $N^{1}$ methylation of compound 20a was carried out using methyl iodide and sodium hydride to obtain compound 20 b in $88 \%$ yield. Then similar to the synthesis of $8-\mathrm{NH}_{2}$-dI phosphoramidite $\mathbf{2 4 a}$, a series of transformations starting from 20 b yielded the cor-

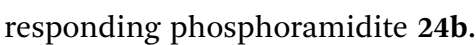

Previously, ${ }^{29}$ 8-Oxo-dI 3 was prepared by enzyme-mediated deamination of 8-Oxo-dA 5. Here, the 8-Oxo-dA ${ }^{50} 5$ nucleoside was deaminated by diazotization of the $6-\mathrm{NH}_{2}$ group using sodium nitrate in acetic acid and water at room temperature for 12 hours, affording 8-Oxo-dI 3 to $77 \%$ yield. Subsequently, compound 3 was tritylated followed by phosphitylation, furnishing the phosphoramidite 26 via 25 (Scheme 4). The spectral and analytical data of 26 were found to be in accordance with that reported. ${ }^{29}$ The free amino group of 8-Oxo-dA 5 was protected with an $\mathrm{N}, \mathrm{N}$-dimethylamino methylidene residue using dimethylformamide dimethyl acetal in methanol. Subsequently, compound 27 was tritylated using DMTrCl in pyridine and DMAP as a catalyst. Furthermore, phosphitylation of the DMTr derivative 28, furnished the phosphoramidite 29.

The amino group of 8-Oxo- $\mathrm{dG}^{51} 4$ was protected with an $\mathrm{N}, \mathrm{N}$ dimethylamino methylidene residue using dimethylformamide dimethyl acetal in methanol afforded compound $\mathbf{3 0}$. Compound $\mathbf{3 0}$ was tritylated and phosphitylated furnishing the required phosphoramidite 32 (Scheme 5).

\section{Oligonucleotide synthesis and hybridization properties}

The oligonucleotides were prepared by using the common phosphoramidite method on a solid support employing a DNA

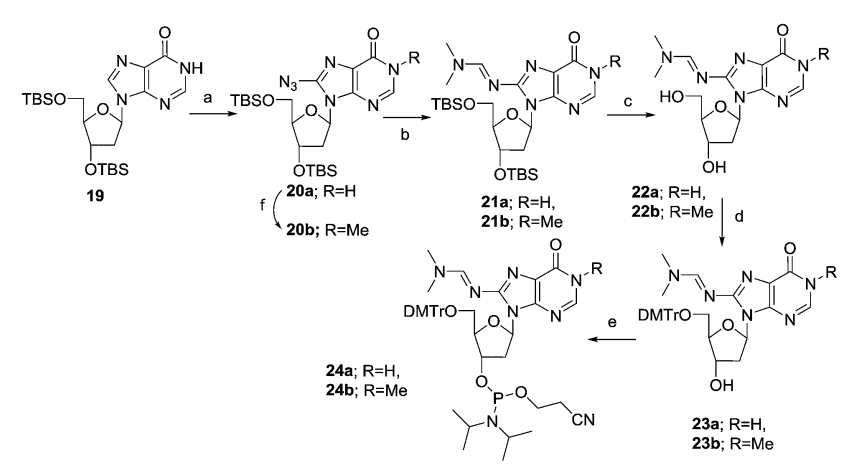

Scheme 3 Synthesis of the phosphoramidite of $8-\mathrm{NH}_{2}-\mathrm{dl}$ and 1-Me$8-\mathrm{NH}_{2}$-dl. Reagents and conditions: (a) $\mathrm{TsN}_{3}, \mathrm{BuLi}, \mathrm{THF},-78{ }^{\circ} \mathrm{C}, 2 \mathrm{~h}$, $60 \%$; (b) (i) $\mathrm{NaBH}_{4}, \mathrm{MeOH}, 0{ }^{\circ} \mathrm{C}$ to rt, $2 \mathrm{~h}$; (ii) DMF-DMA, $\mathrm{MeOH}, 78^{\circ} \mathrm{C}, 1$ h, 70-73\%; (c) TBAF, rt, $3 \mathrm{~h}, 60-73 \%$; (d) $(\mathrm{MeO})_{2} \mathrm{TrCl}$, pyridine, $0{ }^{\circ} \mathrm{C}$ to rt, 12 h, 89-96\%; (e) (i- $\left.\mathrm{Pr}_{2} \mathrm{~N}\right)_{2} \mathrm{POC}_{2} \mathrm{H}_{4} \mathrm{CN}, 1 \mathrm{H}$-tetrazole, $\mathrm{CH}_{2} \mathrm{Cl}_{2}, \mathrm{O}^{\circ} \mathrm{C}$ to rt, $1 \mathrm{~h}, 75-77 \%$; (f) $\mathrm{Mel}, \mathrm{NaH}, 0{ }^{\circ} \mathrm{C}$ to rt, $12 \mathrm{~h}, 88 \%$. 


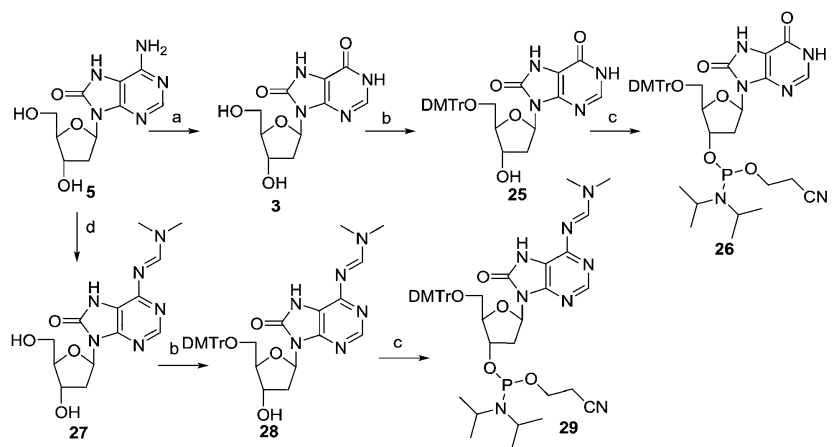

Scheme 4 Synthesis of the phosphoramidite of 8-Oxo-dl and 8-OxodA. Reagents and conditions: (a) $\mathrm{NaNO}_{2}$, acetic acid: $\mathrm{H}_{2} \mathrm{O}, 12 \mathrm{~h}, 77 \%$; (b) $(\mathrm{MeO})_{2} \mathrm{TrCl}$, pyridine, $0{ }^{\circ} \mathrm{C}$ to rt, $12 \mathrm{~h}, 69-73 \%$; (c) $\left(\mathrm{i}-\mathrm{Pr}_{2} \mathrm{~N}\right)_{2} \mathrm{POC}_{2}-$ $\mathrm{H}_{4} \mathrm{CN}, 1 \mathrm{H}$-tetrazole, $\mathrm{CH}_{2} \mathrm{Cl}_{2}, 0{ }^{\circ} \mathrm{C}$ to rt, $1 \mathrm{~h}, 77-80 \%$; (d) DMF-DMA, $\mathrm{MeOH}, 3 \mathrm{~h}, 65^{\circ} \mathrm{C}, 91 \%$.

synthesizer. The base pairing properties of $N^{8}$-8-aza-9-deaza-dG and $N^{8}$-8-aza-dG nucleosides with d-isoC ${ }^{\mathrm{Me}},{ }_{8}^{8} 8-\mathrm{NH}_{2}$-dI, 1-Me-8$\mathrm{NH}_{2}$-dI, 8-Oxo-dI, 8-Oxo-dA, and 8-Oxo-dG were examined by hybridizing oligomers with their complementary strands and determining the $T_{\mathrm{m}}$ of the hybrids by temperature-dependent UV spectroscopy. In order to investigate the base pairing properties, the $N^{8}$-8-aza-dG 1a, $N^{8}$-8-aza-9-deaza-dG 1 b and d-isoG 7 nucleosides were incorporated in the antiparallel duplex $5^{\prime}$ $\mathrm{d}\left(\mathrm{GGT}\right.$ AGC AG*C GGT G)-3' replacing the G residue. The $8-\mathrm{NH}_{2}-$ dI 2a, 1-Me-8- $\mathrm{NH}_{2}$-dI 2b, 8-Oxo-dI 3, 8-Oxo-dA 5, 8-Oxo-dG 4, and d-iso ${ }^{\mathrm{Me}} 6$ nucleosides were incorporated in the sequence $3^{\prime}$ $\mathrm{d}\left(\mathrm{CCA}\right.$ TCG $\mathrm{TC}^{*} \mathrm{G}$ CCA C) $-5^{\prime}$ replacing the $\mathrm{C}$ residue. The strength of hybridization was studied by thermal denaturation experiments, which were determined at $260 \mathrm{~nm}$ in $\mathrm{NaCl}(0.1 \mathrm{M})$ buffer with $\mathrm{KH}_{2} \mathrm{PO}_{4}(20 \mathrm{mM}$, pH 7.5) and EDTA $(0.1 \mathrm{mM})$ at a concentration of $4 \mu \mathrm{m}$ for each strand. The stability of the duplexes was compared to the stability of the natural DNA duplex containing dC:dG (Table 1, entry 1 ) and unnatural<smiles></smiles>
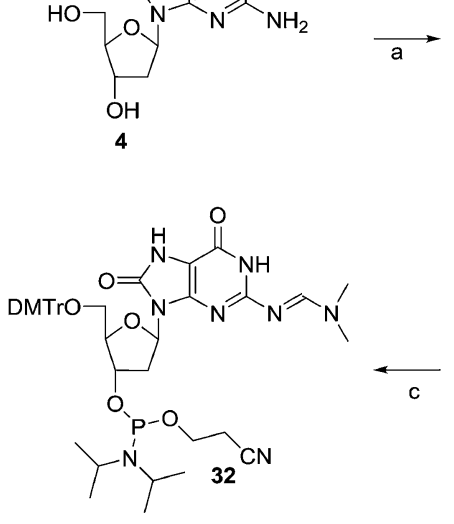

Scheme 5 Synthesis of the phosphoramidite of 8-Oxo-dG. Reagents and conditions: (a) DMF-DMA, $\mathrm{MeOH}, 50 \%$; (b) $(\mathrm{MeO})_{2} \mathrm{TrCl}$, pyridine, $0{ }^{\circ} \mathrm{C}$ to rt, $12 \mathrm{~h}, 71 \%$; (c) (i- $\left.\mathrm{Pr}_{2} \mathrm{~N}\right)_{2} \mathrm{POC}_{2} \mathrm{H}_{4} \mathrm{CN}, 1 \mathrm{H}$-tetrazole, $\mathrm{CH}_{2} \mathrm{Cl}_{2}$, $0{ }^{\circ} \mathrm{C}$ to $\mathrm{rt}, 1 \mathrm{~h}, 81 \%$.
d-isoC $^{\mathrm{Me}}$ :d-isoG (Table 1, entry 2). The $N^{8}$-8-aza-dG:d-isoC ${ }^{\mathrm{Me}}$ base pair gave a less stable duplex than the $\mathrm{dC}: \mathrm{dG}\left(-3.1^{\circ} \mathrm{C}\right)$ pair and d-isoC ${ }^{\mathrm{Me}}$ :d-isoG $\left(-5.4{ }^{\circ} \mathrm{C}\right)$. Incorporation of an $8-\mathrm{NH}_{2}$-dI $2 \mathrm{a}$ versus an $N^{8}$-8-aza-dG nucleoside gave a greater decrease in $T_{\mathrm{m}}$ $\left(-9.5{ }^{\circ} \mathrm{C}\right)$ than incorporation of $\mathrm{d}$-isoC ${ }^{\mathrm{Me}}$ versus $N^{8}$-8-aza-dG nucleoside $\left(-5.4^{\circ} \mathrm{C}\right)$, both decreasing on comparison to the $\mathrm{d}$ isoC ${ }^{\mathrm{Me}}$ :d-isoG base pair. Insertion of the methyl group at $N^{1}$ position of 8- $\mathrm{NH}_{2}$-dI did not affect the duplex stability, which suggests that the base pairing of $8-\mathrm{NH}_{2}$-dI with $N^{8}$-8-aza-dG takes place through Hoogsteen base pairing (Fig. 1). Surprisingly, 8-Oxo-dI and 8-Oxo-dG also show similar duplex stability, compared to $8-\mathrm{NH}_{2}$-dI. As shown in Fig. 3, this could be explained by Wobble type base pairing in which two hydrogen bonds are involved. The sudden decrease in $T_{\mathrm{m}}$ of the duplexes when $N^{8}$-8-aza-dG is placed opposite to 8 -Oxo-dA $\left(-11.2{ }^{\circ} \mathrm{C}\right)$, demonstrated that the $\mathrm{C} 6$ acceptor $(\mathrm{C}=\mathrm{O})$ of 8-Oxo-dI is necessary for base pairing. The experiment proved that the base pair stability for $N^{8}$-8-aza-dG decreases in the order d-isoC ${ }^{\mathrm{Me}}>8$ Oxo-dG $\geq 8$ - $\mathrm{NH}_{2}$-dI $\approx 1$-Me-8- $\mathrm{NH}_{2}$-dI $\geq 8$-Oxo-dI $\gg 8$-Oxo-dA. Approximately similar results were observed for $N^{8}$-8-aza-9deaza-dG 1b, which indicates that the $N^{9}$ nitrogen atom does not play a significant role in duplex stabilization (Table 2).

In order to investigate the selectivity of base pairing, the stability of the duplexes with the modified base $N^{8}$-8-aza-9deaza-dG, $N^{8}$-8-aza-dG, d-isoC ${ }^{\mathrm{Me}}, 8-\mathrm{NH}_{2}$-dI, 1-Me-8- $\mathrm{NH}_{2}$-dI, 8Oxo-dI, 8-Oxo-dA, and 8-Oxo-dG and the four canonical bases (A, $\mathrm{T}, \mathrm{C}$ and $\mathrm{G}$ ) was investigated by $T_{\mathrm{m}}$ determination (Table 3 ). This study is done in function of the potential use of the artificial base pairs in vivo. Among the four inosine derivatives (2a, $2 \mathbf{b}, 3$ and 4) the mismatch discrimination $\left(\Delta T_{\mathrm{m}}\right)$ is the lowest for 8$\mathrm{NH}_{2}$-dI and the highest for 1-Me-8- $\mathrm{NH}_{2}$-dI. For the $N^{8}$ nucleosides; the $N^{8}$-8-aza-9-deaza-dG showed better mismatch discrimination than $N^{8}$-8-aza-dG.

The selectivity of the 1a:2a base pair is low, as the $T_{\mathrm{m}}$ of the duplexes containing 1a:2a are only $1.0-3.4{ }^{\circ} \mathrm{C}$ higher than the

Table $1 T_{m}$ values (in ${ }^{\circ} \mathrm{C}$ ) of non-self-complementary antiparallelstranded oligonucleotide duplexes containing dA, dT, dC, dG, 6 (diso ${ }^{\mathrm{Me}}$ ), and 7 (d-isoG)

\begin{tabular}{|c|c|c|}
\hline Entry & Duplex & $T_{\mathrm{m}}\left({ }^{\circ} \mathrm{C}\right)$ \\
\hline 1 & $\begin{array}{l}5^{\prime}-\mathrm{d}\left(\text { GGT AGC AGC GGT G) }-3^{\prime}\right. \\
3^{\prime}-\mathrm{d}(\text { CCA TCG TCG CCA C)-5 }\end{array}$ & 61.3 \\
\hline 2 & $\begin{array}{l}5^{\prime}-\mathrm{d}(\text { GGT AGC A7C GGT G)--3' } \\
3^{\prime}-\mathrm{d}(\text { CCA TCG T6G CCA C)-5 }\end{array}$ & 63.6 \\
\hline
\end{tabular}

dG: $\mathrm{N}^{8}-1-\mathrm{Me}-8-\mathrm{NH}_{2}-\mathrm{dl}$

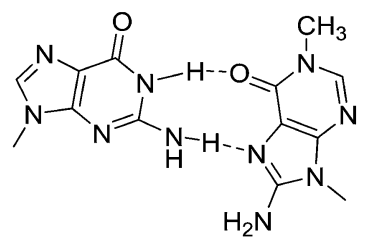<smiles></smiles>

N8-8-Aza-dG:8-Oxo-dl
Fig. 3 Putative base pairs between dG: $N^{8}-1-M e-8-N_{2}-d l$ and $N^{8}-8-$ aza-dG:8-Oxo-dl. 
Table $2 T_{m}$ values (in ${ }^{\circ} \mathrm{C}$ ) of non-self-complementary antiparallelstranded oligonucleotide duplexes containing $1 \mathrm{a}, 1 \mathrm{~b}\left\{5^{\prime}\right.$-d[GGT AGC $\mathrm{A}(1 \mathrm{a}$ or $1 \mathrm{~b}) \mathrm{C}$ GGT G] $\left.-3^{\prime}\right\}$ and $6,2 \mathrm{a}, 2 \mathrm{~b}, 3,4,5$ \{ $3^{\prime}-\mathrm{d}$ [CCA TCG T(6 or 2a or $2 b$ or 3 or 4 or 5$\left.) G(C C A C]-5^{\prime}\right\}$ and $\Delta T_{m}$ with respect to entry 1 (Table 1)

\begin{tabular}{|c|c|c|c|c|}
\hline & $\begin{array}{l}N^{8} \text {-8-aza-dG } \\
\text { (1a) }\end{array}$ & $\Delta T_{\mathrm{m}}$ & $\begin{array}{l}N^{8} \text {-8-aza-9-deaza-dG } \\
(\mathbf{1 b})\end{array}$ & $\Delta T_{\mathrm{m}}$ \\
\hline d-isoC ${ }^{\mathrm{Me}}(\mathbf{6})$ & 58.2 & -3.1 & 58.3 & -3.0 \\
\hline $8-\mathrm{NH}_{2}$-dI (2a) & 54.1 & -7.2 & 54.4 & -6.9 \\
\hline 1-Me-8- $\mathrm{NH}_{2}$-dI $(2 \mathbf{b})$ & 54.0 & -7.3 & 54.0 & -7.3 \\
\hline 8-Oxo-dI (3) & 53.4 & -7.9 & 54.0 & -7.3 \\
\hline 8-Oxo-dG (4) & 54.9 & -6.4 & 55.4 & -5.9 \\
\hline 8-Oxo-dA (5) & 47.0 & -14.3 & 48.6 & -12.7 \\
\hline
\end{tabular}

Table $3 T_{m}$ values (in ${ }^{\circ} \mathrm{C}$ ) of antiparallel-stranded oligonucleotide duplexes containing $1 \mathrm{a}, 1 \mathrm{~b}\left\{5^{\prime}\right.$-d [GGT AGC A(1a or 1b)C GGT G]-3'\} and $2 a, 2 b, 3,4,5\left\{3^{\prime}-d[C C A\right.$ TCG T(2a, or $2 b$ or 3 or 4 , or 5$)$ G CCA C]-5'\} hybridized against complementary oligonucleotides with natural bases

\begin{tabular}{|c|c|c|c|c|c|}
\hline & A & $\mathrm{T}$ & C & G & $\Delta T_{\mathrm{m}}{ }^{a}$ \\
\hline$N^{8}$-8-aza-dG (1a) & 47.1 & 53.8 & 46.9 & 54.6 & 7.7 \\
\hline$N^{8}$-8-aza-9-deaza-dG (1b) & 46.3 & 53.0 & 47.0 & 55.8 & 9.5 \\
\hline 8- $\mathrm{NH}_{2}$-dI (2a) & 50.7 & 51.6 & 53.1 & 52.9 & 2.4 \\
\hline 1-Me-8-NH ${ }_{2}$-dI (2b) & 46.2 & 43.7 & 43.1 & 52.1 & 9.0 \\
\hline 8-Oxo-dI (3) & 55.8 & 50.3 & 53.5 & 47.9 & 7.9 \\
\hline 8-Oxo-dG (4) & 54.7 & 50.0 & 57.0 & 54.9 & 7.0 \\
\hline 8-Oxo-dA (5) & 45.8 & 54.7 & 44.5 & 51.2 & 10.2 \\
\hline
\end{tabular}

${ }^{a}$ In this case $\Delta T_{\mathrm{m}}$ corresponds to the difference between lowest and highest $T_{\mathrm{m}}$ (mismatch discrimination).

$T_{\mathrm{m}}$ of the duplexes of $2 \mathrm{a}$ and the natural bases (A, T, C and G). The selectivity of the 1a:2b base pair is much better, due to

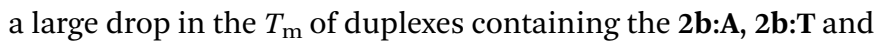
2b:C base pairs. However, discrimination with $\mathrm{G}(\mathbf{2 b}: \mathbf{G}$ base pair) stays low. In case of 8-Oxo-dI 3, the stability of the 3:A is higher than of 3:1a (which is similar than 3:C). Hence the mismatch discrimination is highest with the G base (3:G). 8Oxo-dG (4) shows better base pairing with $\mathrm{C}(\mathbf{4}: \mathbf{C})$ and with $\mathrm{G}$ (4:C), than 8-Oxo-dI (3:C and 3:G). Base pairing of 8-Oxo-dG with canonical bases has been described previously. ${ }^{32}$ Base pair stability of 4:A and 4:G is the same as of 4:1a. The base pair stability of 8-Oxo-dA versus canonical bases decreases in the order of $\mathrm{T}>\mathrm{G} \gg \mathrm{A}>\mathrm{C}$. The results with $\mathbf{1 b}$ are similar to the results with $\mathbf{1 a}$, except that $\mathbf{1 b}: \mathbf{5}$ is somewhat more stable than 1a:5 and 1b:G is somewhat more stable than 1a:G. The result, however, could be sequence dependent. Based on the $T_{\mathrm{m}}$ data, the 1-Me-8- $\mathrm{NH}_{2}$-dI: $N^{8}$-8-aza-dG (or $N^{8}$-8-aza-9-deaza-dG) base pair is the most discriminative versus $\mathrm{A}, \mathrm{T}$, and $\mathrm{C}$, except versus G. However this does not mean that it would be the best orthogonal base pair in vivo.

\section{Recognition of modified bases in vivo}

A range of modified oligonucleosides were chemically synthesized with flanking DNA backbones and subsequently analysed for their biological characteristics in vivo. These oligonucleotides included separately each of $1-\mathrm{Me}-8-\mathrm{NH}_{2}$ - $\mathrm{dI}, 8-\mathrm{NH}_{2}$-dI,
$N^{8}$-8-aza-dG, $\quad N^{8}$-8-aza-9-deaza-dG, 8-Oxo-dI, 8-Oxo-dA and 8-Oxo-dG. The DNA backbone represented the 18-base long coding strand encoding the active site of the essential ThyA enzyme, whereby the nucleosides indicated replaced DNA within various codons (Fig. 4).

\section{XNA-dependent DNA synthesis in vivo}

We investigated the relationship between the nature of the chemical modifications of the 8-derivatives and the response of the $E$. coli genetic system to base pair with sufficient recognition and selectivity to enable survival in vivo. The aim in this study was to identify which of these modified nucleosides lacked such recognition, and possessed poor base-pairing ability with the canonical bases so as to approach orthogonality away from the biological system.

The xenobiotic nucleosides were tested using the published and established gapped-vector assay. ${ }^{52,53}$ In summary, DNA base/ modified nucleoside mosaic oligomers were ligated enzymatically into a gapped form of the inactive thyA gene, which encodes an essential section of the ThyA active site. The inactive thyA gene was located on a plasmid vector (the pAK1/pAK2 heteroduplex) together with the bla ampicillin resistance gene permitting selection on two criteria. Once ligated and circularized, the plasmid was transformed into a strain of E. coli lacking thyA, a lethal growth phenotype in thymidine (dT) deficient media (Fig. 5).

The completion of the thyA gene finalizes the plasmid, which permits bacteria survival in the $\mathrm{dT}$ deficient media. The ratio between bacterial colony numbers in $\pm \mathrm{dT}$ media indicates the success of the mosaic xenobiotic oligonucleotide to serve as a template for DNA polymerization. The mosaic oligonucleotides all took the form of the six middle codons that encode the active site of ThyA around the catalytically essential cysteine (codon TGC or TGT). The forms of each of the oligomers tested follow, including the nucleosides and their positions within the oligomer (Table 4).

The thyA plasmid genes from sixteen clones selected on dT deficient media were sequenced for each mosaic oligonucleotide tested (Fig. 6).

\section{1-Me-8- $\mathrm{NH}_{2}$-dI and 8- $\mathrm{NH}_{2}$-dI}

The assay and interpretation of the 8- $\mathrm{NH}_{2}$-dI and 1-Me-8- $\mathrm{NH}_{2}$ - $\mathrm{dI}$ and nucleotides in vivo follows (Fig. 7).

Analysis of the 1-Me-8- $\mathrm{NH}_{2}$-dI nucleotide in vivo reveals faint recognition as $\mathrm{G}$ and even less as $\mathrm{T}$, with nothing apparent as $\mathrm{C}$ or A. Comparison to the related inosine-derivative $8-\mathrm{NH}_{2}-\mathrm{dI}$, which lacks the $N^{1}$ methyl group, shows that recognition is

\begin{tabular}{|c|c|c|}
\hline $\begin{array}{l}\text { wild-type } E \text {. coli ThyA: } \\
\text { sites of modification }\end{array}$ & 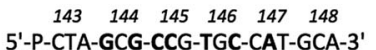 & Amino acid number \\
\hline in mosaic oligos & Leu - Ala - Pro - Cys - His - Ala & - Amino acid - \\
\hline
\end{tabular}

Fig. 4 The general structure of the mosaic test oligos. The 18 bases derive from the wild-type active site of $E$. coli thy A. Their positions and encoded amino acids are shown, including the catalytically essential Cys residue at 146 . The various positions within this sequence where the modified nucleosides were tested within are bolded and underlined. 

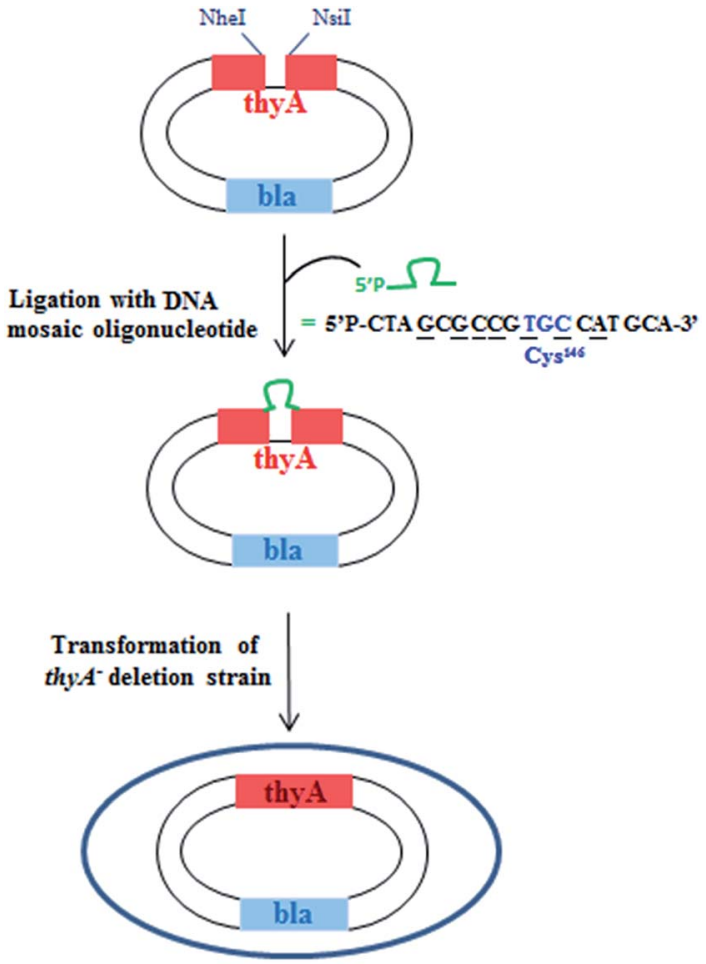

Selection of thy $A^{+}$transformants on medium lacking thymidine

Fig. 5 Selection screen to test DNA oligonucleotides bearing modified base(s) in templates for DNA synthesis in vivo.

entirely as G (and none with the other canonical bases), demonstrating that the presence of this 1-Me group is sufficient to reduce recognition as $\mathrm{G}$ but increase slightly recognition as $\mathrm{T}$.

The 8- $\mathrm{NH}_{2}$-dI nucleotide base pairs the canonical bases in vivo preferentially of the order $\mathrm{C} \ggg \mathrm{T}=\mathrm{G}=\mathrm{A}$, whereas the methylated form 1-Me-8- $\mathrm{NH}_{2}$-dI nucleotide appears to base pair preferentially in the order $\mathrm{C} \gg \mathrm{A}>\mathrm{G}=\mathrm{T}$. These findings agree with the in vitro $T_{\mathrm{m}}$ data interpretations (Table 3), indicating perseverance of the recognition patterns between terminal stabilization in the artificial base pairs and enzymatic polymerization in vivo. Sequencing analysis was performed on purified plasmids from positive transformants and in both experiments revealed only wild-type sequences, indicating no forced changes of the genetic code by the bases.

\section{$N^{8}$-8-aza-dG and $N^{8}$-8-aza-9-deaza-dG}

The assay and interpretation of the two $N^{8}$ nucleosides, $N^{8}-8$ aza-dG and $N^{8}$-8-aza-9-deaza-dG nucleotides in vivo follow (Fig. 8 and 9).

Analysis shows that $N^{8}$-8-aza-dG appears to behave as an A or $\mathrm{C}$ nucleotide, and lacks any recognition as a $\mathrm{T}$ or $\mathrm{G}$ nucleotide. Sequencing of positive colonies revealed the presence of incorporated A's into the XCG codon (changing the amino acid to Thr from Ala, tolerated to approximately $30 \%$ of comparable wild-type survival through DNA control tests). In the GCX codon changes were also observed, with mispairing resulting in the inclusion of silent $\mathrm{C}$ and A residues (tolerated to $100 \%$ as wildtype) for an Ala residue in the enzyme primary structure. The $N^{8}$ 8-aza-dG nucleoside base pairs in the order of $\mathrm{T} \gg \mathrm{G}>\mathrm{C}=\mathrm{A}$. The $N^{8}$-8-aza-9-deaza-dG nucleotide appears to behave similarly to the derivative $N^{8}$-8-aza-dG, with an interpreted base pairing preferentiality of $\mathrm{T} \gg \mathrm{G}=\mathrm{C}=\mathrm{A}$, and similarly a proportion of changes to A nucleotides as observed through sequencing, also in the XCG codon (tolerated to Thr).

We hypothesized that the $N^{9}$ nitrogen atom may assist Hoogsteen base pairing, although the similar findings in vivo between the two $N^{8}$ nucleosides suggests the $N^{9}$ nitrogen atom does not offer a significant role in recognition, agreeing with the previously indicated findings in vitro for this pair with regards to duplex stabilization. Modifications in recognition primarily occur on the XCG, CXT and GCX codons, but the influence remains marginal, as other codons are not affected, indicating little difference in vivo of the recognition of these two $N^{8}$-glycosylated nucleosides. These findings do not discredit the in vitro $T_{\mathrm{m}}$ data, where $N^{8}$-8-aza-dG showed worse mismatch discrimination than its $N^{9}$-deaza-analogue. The general appearance of the in vivo results indicate an agreement to the in vitro findings, where general mismatch is comparably lower in $N^{8}$-8aza-9-deaza-dG except towards $\mathrm{T}$, which appears easier to pair. Between the two nucleosides, the $N^{8}$-8-aza-9-deaza-dG is the most orthogonal of this pair, and one of the most orthogonal of all of those tested in this study.

\section{8-Oxo-dI, 8-Oxo-dG and 8-Oxo-dA}

The assay and interpretation of the 8-Oxo-dI, 8-Oxo-dG and 8-Oxo-dA nucleotides in vivo follow (Fig. 10 and 11).

The response of the 8-Oxo-dI nucleotides reveals the worst in vivo mismatch discrimination of all of the nucleotides tested

Table 4 Sequence of the oligomers used in the XNA-dependent DNA synthesis experiments

Sequence $\left(5^{\prime}-3^{\prime}\right)$

d(P-CTA XCG CCG TGC CAT GCA) d(P-CTA GCG CCG XGC CAT GCA) d(P-CTA GCG CCG TGX CAT GCA) d(P-CTA GCG CCG TGC CXT GCA) d(P-CTA GCX CCT TGT CAT GCA) d(P-CTA GCX CXT TGT CAT GCA) d(P-CTA GCX XCT TGT CAT GCA) d(P-CTA GCX XXT TGT CAT GCA)
$\mathrm{X}$

1-Me-8- $\mathrm{NH}_{2}$-dI, 8- $\mathrm{NH}_{2}$-dI, 8-Oxo-dI, $N^{8}$-8-aza-dG, or $N^{8}$-8-aza-9-deaza-dG 1-Me-8- $\mathrm{NH}_{2}$-dI, 8- $\mathrm{NH}_{2}$-dI, 8-Oxo-dI, $N^{8}$-8-aza-dG, or $N^{8}$-8-aza-9-deaza-dG 1-Me-8- $\mathrm{NH}_{2}$-dI, 8- $\mathrm{NH}_{2}$-dI, 8-Oxo-dI, $N^{8}$-8-aza-dG, or $N^{8}$-8-aza-9-deaza-dG 1-Me-8- $\mathrm{NH}_{2}$-dI, 8- $\mathrm{NH}_{2}$-dI, 8-Oxo-dI, $N^{8}$-8-aza-dG, or $N^{8}$-8-aza-9-deaza-dG 8-Oxo-dI, $N^{8}$-8-aza-dG, $N^{8}$-8-aza-9-deaza-dG, 8-Oxo-dA, or 8-Oxo-dG 8-Oxo-dI, $N^{8}$-8-aza-dG, $N^{8}$-8-aza-9-deaza-dG8-Oxo-dA, or 8-Oxo-dG 8-Oxo-dI, $N^{8}$-8-aza-dG, $N^{8}$-8-aza-9-deaza-dG, 8-Oxo-dA, or 8-Oxo-dG 8-Oxo-dI, $N^{8}$-8-aza-dG, 8-Oxo-dA, or 8-Oxo-dG 


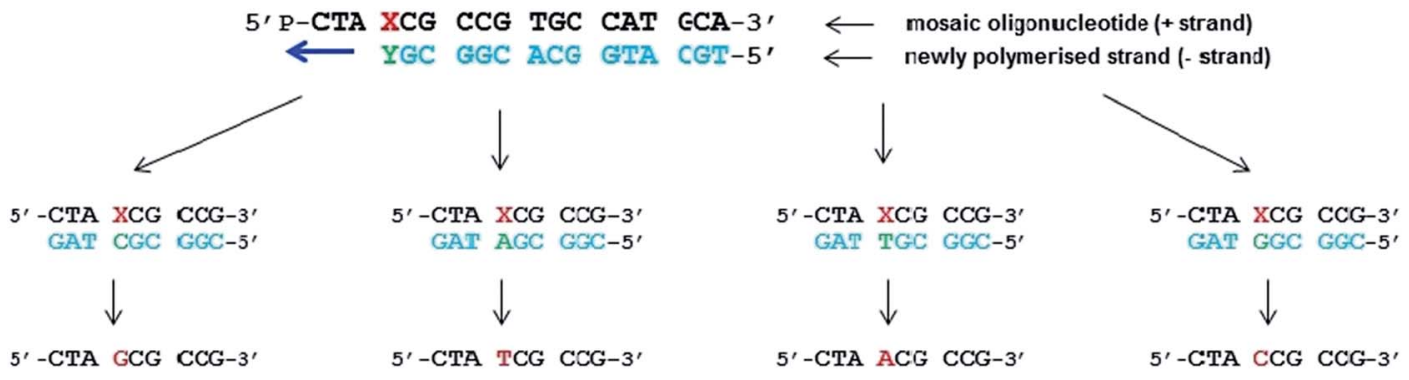

Fig. 6 Fate of mosaic oligomers in vivo. The first step in vivo is the polymerisation of the complementary DNA strand followed by canonical replication. Different possible incorporations of canonical nucleotides facing the base modified DNA nucleoside during the synthesis of the first DNA strand and the resulting coding strand are presented.
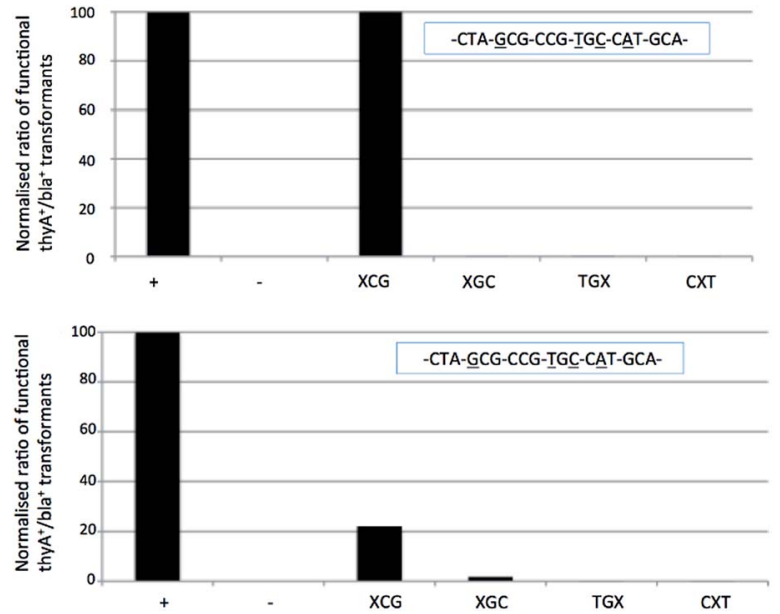

Fig. 7 The in vivo interpretation of the $8-\mathrm{NH}_{2}$-dl nucleotide (top) and 1-Me-8- $\mathrm{NH}_{2}-\mathrm{dl}$ nucleotide (bottom) within the essential thyA gene. The normalized ratio is the experimentally derived average number of thymidine-prototrophic colonies $\left(\mathrm{bla}^{+}\right.$thy $\mathrm{A}^{+}$) from the average total number of colonies ( $\mathrm{bla}^{+}$thy $\mathrm{A}^{-}$and $\mathrm{bla}^{+}$thy $\left.\mathrm{A}^{+}\right)$. The modified section of the oligomer sequence indicates the position/s of the $8-\mathrm{NH}_{2}-\mathrm{dl}$ or 1-Me-8- $\mathrm{NH}_{2}-\mathrm{dl}$ nucleotide as appropriate.

here. Wide base-pairing capabilities with the canonical bases is shown by the apparent survival rates recovered through the tests. As with the previous tests, sequencing was performed of the now thymidine-prototrophic colonies $\left(b l a^{+}\right.$thy $\left.A^{+}\right)$, showing

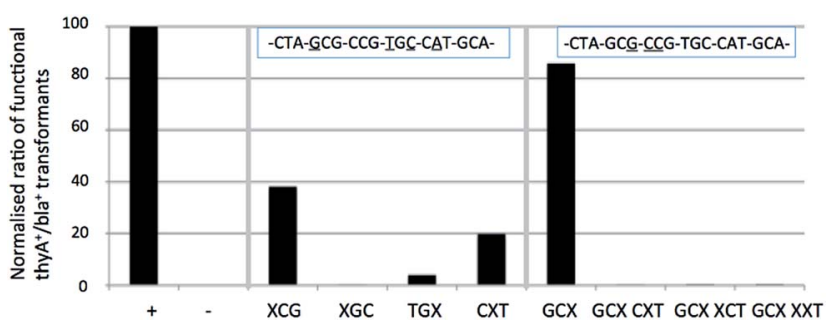

Fig. 8 The in vivo interpretation of the $N^{8}-8$-aza-dG nucleotide within the essential thyA gene. The normalized ratio is the experimentally derived average number of thymidine-prototrophic colonies $\left(\mathrm{bla}^{+}\right.$ thy $\mathrm{A}^{+}$) from the average total number of colonies (bla ${ }^{+}$thy $\mathrm{A}^{-}$and $\mathrm{bla}^{+}$ thy $\mathrm{A}^{+}$). The modified section of the oligomer sequence indicates the position of the $N^{8}-8$-aza-dG nucleotide/s.

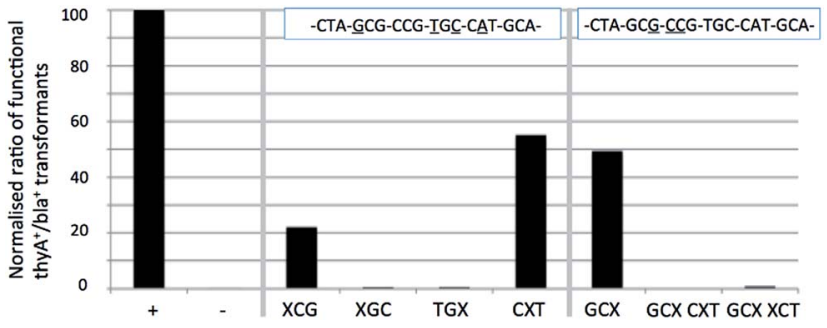

Fig. 9 The in vivo interpretation of the $N^{8}$-8-aza-9-deaza-dG nucleotide within the essential thyA gene. The normalized ratio is the experimentally derived average number of thymidine-prototrophic colonies $\left(\mathrm{bla}^{+}\right.$thy $\left.\mathrm{A}^{+}\right)$from the average total number of colonies $\left(\mathrm{bla}^{+}\right.$ thy $\mathrm{A}^{-}$and $\mathrm{bla}^{+}$thy $\mathrm{A}^{+}$). The modified section of the oligomer sequence indicates the position of the $N^{8}-8$-aza-9-deaza-dG nucleotide/s.

widespread changes to the gene. In the XCG codon, over $80 \%$ of the 8-Oxo-dI nucleotides had become $\mathrm{T}$, changing the amino acid to Ser (tolerated lightly compared to wild-type Ala). Similarly, the codons GCX and (GCX) XCT returned around 15\% each changes to $\mathrm{T}$ (silent change). This nucleotide has a basepairing preferential order of $\mathrm{A}=\mathrm{C}>\mathrm{G} \gg \mathrm{T}$, which support Hoogsteen recognition in vivo.

The in vitro findings and hypothesis of 8-Oxo-dI base pairing stabilities of the order $\mathrm{A}>\mathrm{C}>\mathrm{G}$ agree with the in vivo data. As with all of the nucleotides tested, the contribution of the oligo sequence is important as it imposes restrictions on the result obtained that is not observable in the in vitro work, underlining the importance of these vital tests in the study of modified nucleotides.

The 8-Oxo-dG and 8-Oxo-dA nucleotides show different patterns of base-pairing discrimination. For 8-Oxo-dG, recognition as an $\mathrm{G}$ appears strongest, with weak evidence it behaves as a T, C or A. Base-pairing preferentiality in vivo appears in the order of $\mathrm{C}>\mathrm{T}>\mathrm{A} \gg \mathrm{G}$, with an aversion to base-pairing $\mathrm{G}$ also shown in the sequencing data across the double (GCX) XCT codons, which showed changes towards $\mathrm{G}, \mathrm{T}$ and $\mathrm{A}$ in descending order. The finding of mismatches are largely further agreed upon by the in vitro dataset, although differences imposed by the primary sequence structure are observed in these tests.

The 8-Oxo-dA nucleotide in contrast shows a much cleaner and less promiscuous base-pairing profile than 8 -Oxo-dG. The 


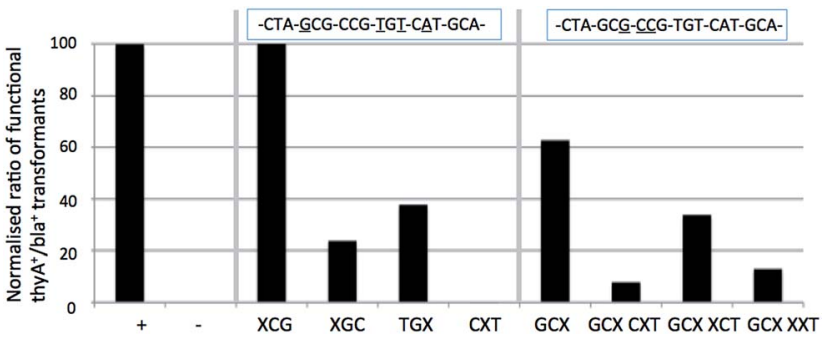

Fig. 10 The in vivo interpretation of the 8-Oxo-dG nucleotide (left) and 8-Oxo-dA nucleotide (right) within the essential thyA gene. The normalized ratio is the experimentally derived average number of thymidine-prototrophic colonies $\left(\mathrm{bla}^{+}\right.$thy $\left.\mathrm{A}^{+}\right)$from the average total number of colonies $\left(\mathrm{bla}^{+}\right.$thy $\mathrm{A}^{-}$and $\mathrm{bla}^{+}$thy $\left.\mathrm{A}^{+}\right)$. The modified section of the oligomer sequence indicates the position of the 8-Oxo-dG and 8-Oxo-dA nucleotide/s, for single (left) and double (right) codons for each.

in vivo data indicates that this nucleotide is strongly recognized as an A, affording a base-pairing order of $\mathrm{T} \gg \mathrm{A} \gg \mathrm{G}=\mathrm{C}$. Sequencing of the positive clones showed widespread changes to A, especially within the GCX codon (tolerating the silent change) and in (GCX) XCT which promoted a change to Thr (with poor in vivo survival compared to wild-type). As with the other nucleotides, the base pairing stability determined in vitro of $\mathrm{T}>\mathrm{G} \gg \mathrm{A}>\mathrm{C}$ agrees well with the findings in vivo, possibly with sequence dependent effects.

It was suspected that the DNA repair pathways of the host test strain of E. coli might have been interacting with and perhaps modifying the 8-oxo modifications of these compounds. It is widely reported that the gene MutM (encoding the MutM DNA glycosylase) can recognize 8-Oxo-dG and remove it from DNA towards protection against mutagenic lesions..$^{44,45}$
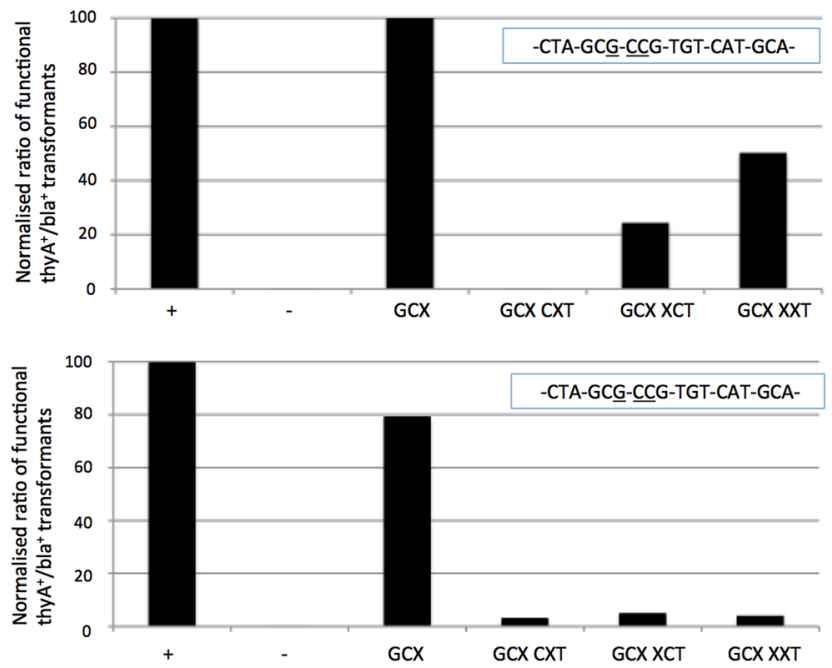

Fig. 11 The in vivo interpretation of the 8-Oxo-dl nucleotide within the essential thyA gene. The normalized ratio is the experimentally derived average number of thymidine-prototrophic colonies $\left(\mathrm{bla}^{+}\right.$ thy $\mathrm{A}^{+}$) from the average total number of colonies $\left(\mathrm{bla}^{+}\right.$thy $\mathrm{A}^{-}$and $\mathrm{bla}^{+}$ thy $\mathrm{A}^{+}$). The modified section of the oligomer sequence indicates the position of the 8-Oxo-dl nucleotide/s, for single (top) and double (bottom) codons.
Accordingly, both 8-Oxo-dG and 8-Oxo-dA nucleotides were tested in the same assay in the equivalent strain of $E$. coli that had been modified in the MutM locus, deleting the gene. On following the same experimental procedure it was revealed that there was in fact no significant difference between the assay response in the strain with and the strain without MutM, indicating that the impact of MutM in this assay format was negligible. This demonstrated that the known mutagenic base (8-Oxo-dG) was not being modified in vivo during our assay by MutM, and therefore not modifying our findings.

\section{Conclusions}

We have developed an efficient route for the synthesis of oligonucleotides containing $N^{8}$-8-aza-dG, $N^{8}$-8-aza-9-deaza-dG, 8- $\mathrm{NH}_{2}$-dI, 1-Me-8- $\mathrm{NH}_{2}$-dI, 8-Oxo-dI, 8-Oxo-dA, and 8-Oxo-dG nucleotides on solid phase support by using phosphoramidite building blocks 18a, 18b, 24a, 24b, 26, 29, and 32 respectively. The base pairing and mismatch discrimination of $N^{8}$-8-aza-9deaza-dG, $N^{8}$-8-aza-dG with d-isoC ${ }^{\mathrm{Me}}$, 8- $\mathrm{NH}_{2}$-dI, 1 -Me-8- $\mathrm{NH}_{2}$-dI, 8-Oxo-dI, 8-Oxo-dA, and 8-Oxo-dG in duplex DNA with antiparallel chain orientation were determined by $T_{\mathrm{m}}$ measurements. The new base pairs form less stable duplexes compared to the $\mathrm{dC}: \mathrm{dG}$ and $\mathrm{d}-\mathrm{isoC}^{\mathrm{Me}}$ :d-isoG pairs. Incorporation of $8-\mathrm{NH}_{2}$ - $\mathrm{dI}$ versus $N^{8}$-8-aza-dG nucleoside gives a greater decrease in $T_{\mathrm{m}}$ than of d-isoC ${ }^{\mathrm{Me}}$ versus $N^{8}$-8-aza-dG. Insertion of the methyl group at $N^{1}$ position of 8- $\mathrm{NH}_{2}$-dI does not affect duplex stability, which suggests that $\mathrm{H}$-bonding with $N^{8}$-8-aza-dG takes place via Hoogsteen base pairing. As could be expected there is no straight correlation between duplex stability ( $T_{\mathrm{m}}$ measurement) and base pair recognition in vivo. For example, $N^{8}$-8-aza-dG is best recognized by $\mathrm{G}$ in vitro $\left(T_{\mathrm{m}}\right)$ and by $\mathrm{T}$ in vivo (E. coli). This, of course, reflects the contribution of the polymerase in basepairing recognition.

From all of the tests in vivo, the compounds belonging to the family of 8-amino-deoxyinosines (1-Me-8- $\mathrm{NH}_{2}$ - $\mathrm{dI}$ and 8- $\mathrm{NH}_{2}$-dI) and $N^{8}$-8-aza-9-deaza-dG have shown to be the most orthogonal from the $E$. coli genetic system and the base-pairing rules of the canonical bases (A, T, G and C). The 8-aza-deoxyguanosines $\left(N^{8}\right.$ 8-aza-dG and $N^{8}$-8-aza-9-deaza-dG) were recognized largely as A (base pairing T), although the 9-deaza modifications affected general pairing with canonical bases and afforded more orthogonality against the unsubstituted $N^{8}$-8-aza-dG. The 9deaza modifications did not change base pairing preferentiality, maintaining the findings observed in vitro.

In testing the 8-Oxo-dG and 8-Oxo-dA nucleosides, a side test was performed after deleting the repair enzyme MutM. This revealed that at least this enzyme was not modifying the 8-oxodeoxynucleosides and therefore not giving an incorrect view into the orthogonality of the nucleoside (as if it had been corrected to a $\mathrm{G}$ through the repair mechanism).

Between the in vitro and in vivo tests it appears that a base pairing of either of the $N^{8}$-glycosylated nucleosides against 8$\mathrm{NH}_{2}$-dI or 1-Me-8- $\mathrm{NH}_{2}$-dI may identify a near orthogonal pair. Poor responses in vivo for these two pairs of nucleosides suggest that they are not strongly pairing with the canonical bases. The biggest problem foreseeable in this pair is the tendency for 
these bases to lack strong discrimination against the canonical base $\mathrm{G}$, although these pairs would be discriminative against A, $\mathrm{T}$ and $\mathrm{C}$.

\section{Experimental section}

${ }^{1} \mathrm{H},{ }^{13} \mathrm{C}$ and ${ }^{31} \mathrm{P}$ NMR spectra were recorded on $300 \mathrm{MHz}\left({ }^{1} \mathrm{H}\right.$ NMR, $300 \mathrm{MHz} ;{ }^{13} \mathrm{C}$ NMR, $75 \mathrm{MHz} ;{ }^{31} \mathrm{P}$ NMR, $\left.121 \mathrm{MHz}\right)$ or 500 $\mathrm{MHz}\left({ }^{1} \mathrm{H}\right.$ NMR, $500 \mathrm{MHz} ;{ }^{13} \mathrm{C}$ NMR, $\left.125 \mathrm{MHz}\right)$ or $600 \mathrm{MHz}\left({ }^{1} \mathrm{H}\right.$ NMR, $600 \mathrm{MHz} ;{ }^{13} \mathrm{C}$ NMR, $150 \mathrm{MHz}$ ) spectrometers. 2D NMRs (H-COSY, HSQC and HMBC) were used for the assignment of all the intermediates and final compounds. Mass spectra were acquired on a quadrupole orthogonal acceleration time-of-flight mass spectrometer. Column chromatographic separations were carried out by gradient elution with suitable combination of two/three solvents and silica gel $(100-200$ mesh or $230-400$ mesh). Solvents for reactions were distilled prior to use: THF and toluene from $\mathrm{Na}$ /benzophenone; $\mathrm{CH}_{2} \mathrm{Cl}_{2}$ and $\mathrm{CH}_{3} \mathrm{CN}$ from $\mathrm{CaH}_{2} ; \mathrm{Et}_{3} \mathrm{~N}$ and pyridine from $\mathrm{KOH}$.

\section{5-Amino-2-(2,3,5-O-triacetyl- $\beta$-D-ribofuranosyl)- $2 \mathrm{H}$-[1,2,3] triazolo[ $[4,5-d]$ pyrimidin-7-one (9)}

$\beta$-D-Ribofuranose-1,2,3,5-tetraacetate $(8.06 \mathrm{~g}, 23.01 \mathrm{mmol})$ was added to a solution of compound $8(3.50 \mathrm{~g}, 25.31 \mathrm{mmol})$ in acetonitrile $(115 \mathrm{~mL})$. The reaction mixture was heated to $75{ }^{\circ} \mathrm{C}$ and boron trifluoride diethyl etherate $(3.03 \mathrm{~mL}, 24.16 \mathrm{mmol})$ was added. After $3 \mathrm{~h}$ the volatiles were removed in vacuo and the residue was purified by flash chromatography (hexane/EtOAc $7: 3)$ to give the product $9(5.10 \mathrm{~g}, 54 \%) .{ }^{1} \mathrm{H}$ NMR $(300 \mathrm{MHz}$, DMSO- $d_{6}$ ): $\delta 11.01$ (br s, $\left.1 \mathrm{H}, \mathrm{NH}\right), 6.67\left(\mathrm{br} \mathrm{s}, 2 \mathrm{H}, \mathrm{NH}_{2}\right), 6.32(\mathrm{~d}, J$ $\left.=2.8 \mathrm{~Hz}, 1 \mathrm{H}, \mathrm{H}-1^{\prime}\right), 5.84-5.75\left(\mathrm{~m}, 1 \mathrm{H}, \mathrm{H}-2^{\prime}\right), 5.68-5.49(\mathrm{~m}, 1 \mathrm{H}$, $\left.\mathrm{H}-3^{\prime}\right), 4.54-4.33\left(\mathrm{~m}, 2 \mathrm{H}, \mathrm{H}-4^{\prime}, \mathrm{H}-5 \mathrm{a}^{\prime}\right), 4.07$ (dd, $J=12.1,4.8 \mathrm{~Hz}$, $\left.1 \mathrm{H}, \mathrm{H}-5 \mathrm{~b}^{\prime}\right), 2.09\left(\mathrm{~s}, 6 \mathrm{H}, \mathrm{CH}_{3}\right), 1.98\left(\mathrm{~s}, 3 \mathrm{H}, \mathrm{CH}_{3}\right) ;{ }^{13} \mathrm{C}$ NMR $(75$ MHz, DMSO- $\left.d_{6}\right): \delta 169.9(\mathrm{C}=\mathrm{O}), 169.5(\mathrm{C}=\mathrm{O}), 169.2(\mathrm{C}=\mathrm{O})$, 159.6 (C7), 156.5 (C3a), 154.6 (C5), 128.0 (C7a), 93.6 (C1'), 80.0 (C4'), 73.2 (C3'), 70.3 (C2'), 62.3 (C5'), 20.4, $20.3\left(\mathrm{CH}_{3}\right)$; HRMS (ESI+) calcd for $\mathrm{C}_{15} \mathrm{H}_{18} \mathrm{~N}_{6} \mathrm{NaO}_{8}[\mathrm{M}+\mathrm{Na}]^{+} 433.1078$, found 433.1076 .

\section{5-Amino-2-( $\beta$-D-ribofuranosyl)-2 $H$-[1,2,3]triazolo[ $[4,5-d]$ pyrimidin-7-one $(10 a)^{46}$}

Concentrated ammonium hydroxide $(48 \mathrm{~mL})$ solution was added to compound $9(5 \mathrm{~g}, 12.19 \mathrm{mmol})$ and the mixture was stirred for $8 \mathrm{~h}$ at room temperature. The aqueous solution was dried by lyophilization. The residue was purified by flash column chromatography $\left(\mathrm{CH}_{2} \mathrm{Cl}_{2} / \mathrm{MeOH} 8.5: 1.5\right)$ to yield the title compound 10a as a white solid (3.17 g, 91\%). ${ }^{1} \mathrm{H}$ NMR (300 MHz, DMSO- $d_{6}$ ): $\delta 10.96$ (br s, $1 \mathrm{H}, \mathrm{NH}$ ), 6.57 (br s, $2 \mathrm{H}, \mathrm{NH}_{2}$ ), 5.87 (d, $J=3.8 \mathrm{~Hz}, 1 \mathrm{H}, \mathrm{H}-1^{\prime}$ ), $5.60(\mathrm{br} \mathrm{s}, 1 \mathrm{H}, \mathrm{OH}), 5.24(\mathrm{br} \mathrm{s}, 1 \mathrm{H}, \mathrm{OH})$, 4.79-4.77 (m, $1 \mathrm{H}, \mathrm{OH}), 4.49-4.48\left(\mathrm{~m}, 1 \mathrm{H}, \mathrm{H}-2^{\prime}\right), 4.25-4.21(\mathrm{~m}$, $\left.1 \mathrm{H}, \mathrm{H}-3^{\prime}\right), 4.00-3.97\left(\mathrm{~m}, 1 \mathrm{H}, \mathrm{H}-4^{\prime}\right), 3.60-3.56\left(\mathrm{~m}, 1 \mathrm{H}, \mathrm{H}-5 \mathrm{a}^{\prime}\right)$, 3.50-3.44 (m, $\left.1 \mathrm{H}, \mathrm{H}-5 \mathrm{~b}^{\prime}\right) ;{ }^{13} \mathrm{C}\left(75 \mathrm{MHz}\right.$, DMSO- $\left.d_{6}\right): \delta 159.6$ (C7), 156.8 (C3a), 154.5 (C5), 127.5 (C7a), 96.8 (C1'), 86.2 (C4'), 74.6 (C3'), $70.8\left(\mathrm{C2}^{\prime}\right), 62.2\left(\mathrm{C}^{\prime}\right)$; HRMS (ESI+) calcd for $\mathrm{C}_{9} \mathrm{H}_{12} \mathrm{~N}_{6} \mathrm{NaO}_{5}$ $[\mathrm{M}+\mathrm{Na}]^{+}$307.0761, found 307.0772.
5-Amino-2-[3,5-O-(1,1,3,3-tetraisopropyldisiloxane-1,3-diyl)- $\beta$ D-ribofuranosyl]-2H-[1,2,3]triazolo[4,5- $d]$ pyrimidin-7-one (14a)

To a suspension of the intermediate $10 \mathrm{a}(3 \mathrm{~g}, 10.55 \mathrm{mmol})$, in anhydrous pyridine $(52 \mathrm{~mL})$ under argon atmosphere, 1,3dichloro-1,1,3,3-tetraisopropyldisiloxane (3.63 mL, $11.61 \mathrm{mmol}$ ) at $0{ }^{\circ} \mathrm{C}$ was added and then the mixture was stirred at room temperature for $8 \mathrm{~h}$. The reaction was quenched by the addition of $\mathrm{MeOH}$. The solvents were evaporated and the product 14a (4.3 g, 77\%) was isolated by flash column chromatography (hexane/EtOAc $1: 1) .{ }^{1} \mathrm{H}$ NMR $\left(600 \mathrm{MHz}\right.$, DMSO- $\left.d_{6}\right): \delta 11.09$ (br $\mathrm{s}, 1 \mathrm{H}, \mathrm{NH}), 6.62\left(\mathrm{br} \mathrm{s}, 2 \mathrm{H}, \mathrm{NH}_{2}\right), 5.89\left(\mathrm{~s}, 1 \mathrm{H}, \mathrm{H}-1^{\prime}\right), 5.75(\mathrm{~d}, J=4.6$ $\mathrm{Hz}, 1 \mathrm{H}, \mathrm{OH}), 4.89\left(\mathrm{dd}, J=8.5,4.6 \mathrm{~Hz}, 1 \mathrm{H}, \mathrm{H}-3^{\prime}\right), 4.44(\mathrm{t}, J=3.7$ $\left.\mathrm{Hz}, 1 \mathrm{H}, \mathrm{H}-2^{\prime}\right), 4.05-3.99$ (m, 1H, H-5a'), 3.95-3.79 (m, 2H, H-4', $\left.\mathrm{H}-5 \mathrm{~b}^{\prime}\right), 1.12-0.87\left[\mathrm{~m}, 28 \mathrm{H}, 4 \times \mathrm{CH}\left(\mathrm{CH}_{3}\right)_{2}\right] ;{ }^{13} \mathrm{C} \mathrm{NMR}(151 \mathrm{MHz}$, DMSO- $d_{6}$ ): $\delta 159.7$ (C7), 156.8 (C3a), 154.7 (C5), 127.5 (C7a), 96.2 (C1'), 81.4 (C4'), $74.4\left(\mathrm{C}^{\prime}\right), 71.5\left(\mathrm{C}^{\prime}\right), 61.6\left(\mathrm{C5}^{\prime}\right)$, 17.4, 17.3, 17.2, 17.1, 17.0, 16.96, 16.91, 12.8, 12.5, 12.3, 12.2, $12.1\left[\mathrm{CH}\left(\mathrm{CH}_{3}\right)_{2}\right]$; HRMS (ESI+) calcd for $\mathrm{C}_{21} \mathrm{H}_{38} \mathrm{~N}_{6} \mathrm{NaO}_{6} \mathrm{Si}_{2}[\mathrm{M}+\mathrm{Na}]^{+}$527.2463, found 527.2469.

5-Amino-2-[3,5-O-(1,1,3,3-tetraisopropyldisiloxane-1,3-diyl)-2deoxy- $\beta$-D-ribofuranosyl]-2H-[1,2,3]triazolo[4,5- $d]$ pyrimidin-7one (15a)

Compound 14a $(2 \mathrm{~g} ; 3.80 \mathrm{mmol})$ was treated with $1,1^{\prime}$-thiocarbonyldiimidazole $(0.676 \mathrm{~g} ; 3.80 \mathrm{mmol})$ in dry $\mathrm{CH}_{2} \mathrm{Cl}_{2}(38 \mathrm{~mL})$ for $8 \mathrm{~h}$ at room temperature under argon atmosphere. The solvent was evaporated and the residue was dissolved in $\mathrm{CH}_{2} \mathrm{Cl}_{2}$ (20 mL) and washed with $\mathrm{H}_{2} \mathrm{O}(10 \mathrm{~mL})$. The aqueous layer was extracted twice with $\mathrm{CH}_{2} \mathrm{Cl}_{2}(10 \mathrm{~mL})$; the combined organic layers were dried over $\mathrm{Na}_{2} \mathrm{SO}_{4}$ and evaporated. The crude product obtained as slightly yellow foam, was used without further purification in the next step. The crude product was dissolved in dry toluene $(76 \mathrm{~mL})$, AIBN $(0.125 \mathrm{~g} ; 0.76 \mathrm{mmol})$ and $\mathrm{Bu}_{3} \mathrm{SnH}(2.56 \mathrm{~mL} ; 9.50 \mathrm{mmol})$ were added under argon atmosphere and the mixture was degassed with argon for $15 \mathrm{~min}$. Afterwards, the reaction was heated at $75{ }^{\circ} \mathrm{C}$ for $2 \mathrm{~h}$. The solution was evaporated in vacuo, and the product was purified by flash chromatography (hexane/EtOAc $1: 1$ ). The compound 15a was obtained as white solid (1.20 g, 62\% over two steps). ${ }^{1} \mathrm{H}$ NMR (600 MHz, DMSO- $\left.d_{6}\right): \delta 11.46(\mathrm{~s}, 1 \mathrm{H}, \mathrm{NH}), 6.87(\mathrm{~s}, 2 \mathrm{H}$, $\mathrm{NH}_{2}$ ), 6.30 (d, $\left.J=7.5 \mathrm{~Hz}, 1 \mathrm{H}, \mathrm{H}-1^{\prime}\right), 5.12\left(\mathrm{~m}, 1 \mathrm{H}, \mathrm{H}-3^{\prime}\right), 3.91-3.79$ (m, 2H, H-4' $\left.\mathrm{H}^{\prime}-5 \mathrm{a}^{\prime}\right), 3.72$ (dd, $\left.J=12.3,8.8 \mathrm{~Hz}, 1 \mathrm{H}, \mathrm{H}-5 \mathrm{~b}^{\prime}\right), 2.79$ $\left(\mathrm{m}, 1 \mathrm{H}, \mathrm{H}-2 \mathrm{a}^{\prime}\right), 2.64-2.50\left(\mathrm{~m}, 1 \mathrm{H}, \mathrm{H}-2 \mathrm{~b}^{\prime}\right),[\mathrm{m}, 28 \mathrm{H}, 4 \times$ $\left.\mathrm{CH}\left(\mathrm{CH}_{3}\right)_{2}\right] \cdot{ }^{13} \mathrm{C}$ NMR (151 MHz, DMSO- $\left.d_{6}\right): \delta 159.6(\mathrm{C} 7), 157.0$ (C3a), 155.1 (C5), 127.3 (C7a), 91.0 (C1'), 84.8 (C4'), 72.6 (C3'), $63.6\left(\mathrm{C}^{\prime}\right), 40.1\left(\mathrm{C}^{\prime}\right), 17.3,17.3,17.2,17.1,16.9,16.83,16.81$, $12.7,12.5,12.2,12.1,12.0\left[\mathrm{CH}\left(\mathrm{CH}_{3}\right)_{2}\right]$. HRMS (ESI+) calcd for $\mathrm{C}_{21} \mathrm{H}_{39} \mathrm{~N}_{6} \mathrm{O}_{5} \mathrm{Si}_{2}[\mathrm{M}+\mathrm{H}]^{+}$511.2514, found 511.2517.

\section{5-Amino-2-(2-deoxy- $\beta$-D-ribofuranosyl)-2H-[1,2,3]triazolo[4,5- d] pyrimidin-7-one (1a) ${ }^{21}$}

Compound 15a (1.1 g; $2.15 \mathrm{mmol})$ was dissolved in dry THF $(14 \mathrm{~mL})$ and tetrabutylammonium fluoride solution $1.0 \mathrm{M}$ in THF ( $6.46 \mathrm{~mL}, 6.46 \mathrm{mmol})$ was added. The reaction was stirred 
for $3 \mathrm{~h}$ at room temperature. The solvent was evaporated in vacuo, and the crude residue was purified by flash chromatography $\left(\mathrm{CH}_{2} \mathrm{Cl}_{2} / \mathrm{MeOH} 9: 1\right)$ to yield the product $1 \mathrm{a}$ as white solid $(0.560 \mathrm{~g}, 97 \%)$. Spectral and analytical data were in agreement with previous report. ${ }^{21}$

\section{2-(2-Deoxy- $\beta$-D-ribofuranosyl)-5-(dimethylaminomethylidene)- $2 H-[1,2,3]$ triazolo[ $[4,5-d]$ pyrimidin-7-one $(16 a)^{21}$}

To a solution of compound 1a $(0.50 \mathrm{~g}, 1.86 \mathrm{mmol})$ in $\mathrm{MeOH}$ $(12 \mathrm{~mL})$ was added dimethylformamide dimethyl acetal $(499 \mu \mathrm{L}$, $3.73 \mathrm{mmol}$ ), and the mixture was heated at $50{ }^{\circ} \mathrm{C}$ for $1 \mathrm{~h}$. The reaction was cooled to room temperature and concentrated under reduced pressure. The crude residue was purified by flash column chromatography $\left(\mathrm{CH}_{2} \mathrm{Cl}_{2} / \mathrm{MeOH} 95: 5\right)$ to yield the compound 16a as a white solid (0.56 g, 93\%). Spectral and analytical data were in agreement with previous report. ${ }^{21}$

\section{2-(5-O-Dimethoxytrityl-2-deoxy- $\beta$-D-ribofuranosyl)-5- (dimethylaminomethylidene)-2H-[1,2,3]triazolo $[4,5-d]$ pyrimidin-7-one $(17 a)^{21}$}

The compound 16a (0.50 g, $1.55 \mathrm{mmol})$ was co-evaporated with dry pyridine twice under argon atmosphere and then dissolved in dry pyridine $(15 \mathrm{~mL}) .4,4^{\prime}$-Dimethoxytrityl chloride $(0.524 \mathrm{~g}$, $1.55 \mathrm{mmol})$ in $\mathrm{CH}_{2} \mathrm{Cl}_{2}(1.5 \mathrm{~mL})$ was slowly added drop wise under argon atmosphere at $0{ }^{\circ} \mathrm{C}$, then the mixture was stirred at room temperature for $2 \mathrm{~h}$. The reaction was quenched by the addition of $\mathrm{MeOH}$ and the solvents were evaporated. The residue was dissolved in $\mathrm{CH}_{2} \mathrm{Cl}_{2}$ and washed with $\mathrm{H}_{2} \mathrm{O}$, the organic layers were dried on $\mathrm{Na}_{2} \mathrm{SO}_{4}$ and evaporated under argon atmosphere. The compound 17a was isolated by column chromatography $\left(\mathrm{CH}_{2} \mathrm{Cl}_{2} / \mathrm{MeOH} / \mathrm{TEA} 97: 2: 1\right)$ as a white solid (0.81 g, 83\%). Spectral and analytical data were in agreement with previous report. ${ }^{21}$

\section{2-(5-O-Dimethoxytrityl-2-deoxy- $\beta$-D-ribofuranosyl)-5- (dimethylaminomethylidene)-2H-[1,2,3]triazolo[4,5- $d]$ pyrimidin-7-one-4-(2-cyanoethyl- $N, N$-diisopropyl) phosphoramidite (18a)}

To a stirred solution of $17 \mathrm{a}(0.320 \mathrm{~g}, 0.511 \mathrm{mmol})$ and $1 \mathrm{M}$ solution of bis(diisopropylamino)(2-cyanoethoxy)phosphine $(767 \mu \mathrm{L}, 0.767 \mathrm{mmol})$ in anhydrous $\mathrm{CH}_{2} \mathrm{Cl}_{2}(4 \mathrm{~mL})$, under argon atmosphere and at $0{ }^{\circ} \mathrm{C}$, was added $0.45 \mathrm{M}$ solution of $1 \mathrm{H}$-terazole (1.13 mL, $0.562 \mathrm{mmol}$ ) dropwise. After $10 \mathrm{~min}$, the ice bath was removed and reaction mixture was allowed to stir at room temperature for $45 \mathrm{~min}$. The reaction mixture was diluted with $\mathrm{CH}_{2} \mathrm{Cl}_{2}$ and was washed with $1 \mathrm{M}$ TEAB solution. The extracts were dried over $\mathrm{Na}_{2} \mathrm{SO}_{4}$ and concentrated in vacuo. The crude mixture was purified by flash column chromatography (hexane/ acetone/TEA, $65: 34: 1)$ to afford amidite 18a $(0.310 \mathrm{~g}, 73 \%$ yield). ${ }^{31} \mathrm{P}$ NMR (121 MHz, $\mathrm{CDCl}_{3}$ ) $\delta$ 149.3, 149.2. HRMS (ESI+) calcd for $\mathrm{C}_{42} \mathrm{H}_{53} \mathrm{~N}_{9} \mathrm{O}_{7} \mathrm{P}[\mathrm{M}+\mathrm{H}]^{+}$826.3799, found 826.3818. ${ }^{3}$

Ethyl 1-(2,3,5-O-triacetyl- $\beta$-D-ribofuranosyl)-4-nitro-1Hpyrazole-3-carboxylate (12)

To the compound 11 (1.85 g, $10 \mathrm{mmol})$ in $66 \mathrm{~mL}$ of 1,2-dichloroethane, $N, O$-bis(trimethylsilyl) acetamide $(4.9 \mathrm{~mL}, 20 \mathrm{mmol})$ was added and the reaction was stirred for 30 minutes at room temperature. Afterwards, $\beta$-D-ribofuranose-1,2,3,5-tetraacetate $(3.18 \mathrm{~g}, 10 \mathrm{mmol})$ was added into the reaction mixture, followed by $1 \mathrm{M}$ solution of stannic chloride in $\mathrm{CH}_{2} \mathrm{Cl}_{2}(8 \mathrm{~mL}, 8 \mathrm{mmol})$ and the resulting mixture was stirred at room temperature for $36 \mathrm{~h}$. The reaction solution was quenched with cold saturated aq. $\mathrm{NaHCO}_{3}(20 \mathrm{~mL})$ and extracted with $\mathrm{CH}_{2} \mathrm{Cl}_{2}$. The organics were washed with sat. aq. $\mathrm{NaHCO}_{3}(2 \times 15 \mathrm{~mL})$ and brine $(2 \times$ $15 \mathrm{~mL}$ ), dried over $\mathrm{MgSO}_{4}$, filtered, concentrated, and purified by flash column chromatography (hexane/EtOAc $7: 3$ ) to give compound $12(3.8 \mathrm{~g}, 85 \%)$ as light yellow oil. ${ }^{1} \mathrm{H} \mathrm{NMR}(300 \mathrm{MHz}$, $\mathrm{CDCl}_{3}$ ): $\delta 8.47$ (s, $\left.1 \mathrm{H}, \mathrm{H}-5\right), 5.91\left(\mathrm{~d}, J=2.9,1 \mathrm{H}, \mathrm{H}-1^{\prime}\right), 5.70$ (dd, $\left.J=5.2,2.9 \mathrm{~Hz}, 1 \mathrm{H}, \mathrm{H}-2^{\prime}\right), 5.45\left(\mathrm{dd}, J=6.2,5.2 \mathrm{~Hz}, 1 \mathrm{H}, \mathrm{H}-3^{\prime}\right)$, 4.47-4.22 (m, $4 \mathrm{H}, \mathrm{H}-4^{\prime}, \mathrm{H}-5 \mathrm{a}^{\prime}, \mathrm{OCH}_{2}$ ), 4.25 (dd, $J=12.5,3.6 \mathrm{~Hz}$, $\left.1 \mathrm{H}, \mathrm{H}-5 \mathrm{~b}^{\prime}\right), 2.15\left(\mathrm{~s}, 6 \mathrm{H}, \mathrm{CH}_{3}\right), 2.07\left(\mathrm{~s}, 3 \mathrm{H}, \mathrm{CH}_{3}\right), 1.38(\mathrm{t}, J=7.1$ $\left.\mathrm{Hz}, 3 \mathrm{H}, \mathrm{CH}_{3}\right) ;{ }^{13} \mathrm{C}\left(75 \mathrm{MHz}, \mathrm{CDCl}_{3}\right): \delta 170.2,169.2,169.0(\mathrm{C}=\mathrm{O})$, $159.8(\mathrm{C}=\mathrm{O}), 140.1$ (C4), 134.2 (C3), 129.3 (C5), 92.5 (C1'), 80.6 $\left(\mathrm{C}^{\prime}\right), 74.2\left(\mathrm{C}^{\prime}\right), 69.5\left(\mathrm{C}^{\prime}\right), 62.5\left(\mathrm{C5}^{\prime}\right), 62.0\left(\mathrm{CH}_{2} \mathrm{O}\right), 20.5,20.2$, $13.8\left(\mathrm{CH}_{3}\right)$; HRMS (ESI+) calcd for $\mathrm{C}_{17} \mathrm{H}_{21} \mathrm{~N}_{3} \mathrm{O}_{11}[\mathrm{M}+\mathrm{Na}]^{+}$ 466.1068, found 466.1063 .

\section{Ethyl 4-amino-1-(2,3,5-O-triacetyl- $\beta$-D-ribofuranosyl)- $1 \mathrm{H}$ - pyrazole-3 (13)}

To a solution of compound 12 (3.7 g, $8.35 \mathrm{mmol})$ in $\mathrm{MeOH}$ (41 $\mathrm{mL}$ ) was added $10 \% \mathrm{Pd} / \mathrm{C}(88 \mathrm{mg})$, and the mixture was stirred at room temperature for $8 \mathrm{~h}$ under a hydrogen atmosphere (1 atm). The catalyst was removed by filtration over celite. The filtrate was concentrated and compound 13 (3.45 g, 100\%) was used as such in the next step. ${ }^{1} \mathrm{H}$ NMR (300 MHz, DMSO- $d_{6}$ ): $\delta 7.38$ (s, $1 \mathrm{H}, \mathrm{H}-5), 5.99$ (d, $\left.J=4.2 \mathrm{~Hz}, 1 \mathrm{H}, \mathrm{H}-1^{\prime}\right), 5.70$ (dd, $J=5.2$, $\left.2.9 \mathrm{~Hz}, 1 \mathrm{H}, \mathrm{H}-2^{\prime}\right), 5.45$ (dd, $\left.J=6.2,5.2 \mathrm{~Hz}, 1 \mathrm{H}, \mathrm{H}-3^{\prime}\right), 4.47-4.22$ ( $\mathrm{m}, 4 \mathrm{H}, \mathrm{H}-4^{\prime}, \mathrm{H}-5 \mathrm{a}^{\prime}, \mathrm{OCH}_{2}$ ), 4.25 (dd, $J=3.6,12.5 \mathrm{~Hz}, 1 \mathrm{H}, \mathrm{H}-5 \mathrm{~b}^{\prime}$ ), $2.15\left(\mathrm{~s}, 6 \mathrm{H}, \mathrm{CH}_{3}\right), 2.07\left(\mathrm{~s}, 3 \mathrm{H}, \mathrm{CH}_{3}\right), 1.28\left(\mathrm{t}, J=7.1 \mathrm{~Hz}, 3 \mathrm{H}, \mathrm{CH}_{3}\right)$; ${ }^{13} \mathrm{C}\left(75 \mathrm{MHz}, \mathrm{DMSO}-d_{6}\right): \delta 170.1,169.5,169.3,162.8(\mathrm{C}=\mathrm{O})$, 135.7 (C4), 130.6 (C3), 116.2 (C5), 90.7 (C1'), 79.6 (C4'), 72.9 $\left(\mathrm{C}^{\prime}\right)$, $70.4\left(\mathrm{C2}^{\prime}\right), 62.8\left(\mathrm{C5}^{\prime}\right), 59.8\left(\mathrm{CH}_{2} \mathrm{O}\right), 20.5,20.3,14.3\left(\mathrm{CH}_{3}\right)$; HRMS (ESI+) calcd for $\mathrm{C}_{17} \mathrm{H}_{23} \mathrm{~N}_{3} \mathrm{O}_{9}[\mathrm{M}+\mathrm{Na}]^{+} 436.1326$, found 436.1331 .

\section{5-Amino-2-( $\beta$-D-ribofuranosyl)-2H-pyrazolo[4,3- $d]$ pyrimidin-7- one (10b)}

A mixture of 13 (1.2 g, $2.9 \mathrm{mmol})$, chloroformamidine hydrochloride (0.84 g, $7.26 \mathrm{mmol})$ and dimethylsulfone $(1.37 \mathrm{~g}, 14.5$ $\mathrm{mmol}$ ), was heated for 1 hour at $120{ }^{\circ} \mathrm{C}$ in an open flask with magnetic stirring. After the mixture was cooled to room temperature, $\mathrm{H}_{2} \mathrm{O}(5 \mathrm{~mL})$ was added. The solution was then neutralized with $\mathrm{NH}_{4} \mathrm{OH}$, stirred for $1 \mathrm{~h}$ and then the aqueous solution was dried by lyophilization. The crude residue was purified by flash column chromatography $\left(\mathrm{CH}_{2} \mathrm{Cl}_{2} / \mathrm{MeOH} 8: 2\right)$ to yield the compound $10 \mathrm{~b}$ as a white solid $(0.35 \mathrm{~g}, 42 \%) .{ }^{1} \mathrm{H}$ NMR (300 MHz, DMSO- $d_{6}$ ): $\delta 10.95$ (br s, $1 \mathrm{H}, \mathrm{NH}$ ), 8.00 (s, $1 \mathrm{H}, \mathrm{H}-$ 9), 6.07 (br s, 2H, $\mathrm{NH}_{2}$ ), 5.72 (d, $\left.J=4.1 \mathrm{~Hz}, 1 \mathrm{H}, \mathrm{H}-1^{\prime}\right), 5.54$ (d, $J=$ $5.0 \mathrm{~Hz}, 1 \mathrm{H}, \mathrm{OH}), 5.19(\mathrm{~m}, 1 \mathrm{H}, \mathrm{OH}), 4.98(\mathrm{t}, J=5.8 \mathrm{~Hz}, 1 \mathrm{H}, \mathrm{OH})$, 4.31-4.29 (m, 1H, H-2'), 4.14-4.09 (m, 1H, H-3'), 3.95-3.91 (m, $1 \mathrm{H}, \mathrm{H}-4^{\prime}$ ), 3.65-3.60 (m, 1H, H-5a'), 3.54-3.33 (m, $\left.1 \mathrm{H}, \mathrm{H}-5 \mathrm{~b}^{\prime}\right) ;{ }^{13} \mathrm{C}$ (75 MHz, DMSO- $d_{6}$ ): $\delta 157.3$ (C7), 151.2 (C5), 139.3 (C3a), 133.4 
(C7a), 119.5 (C3), 94.9 (C1'), $85.4\left(\mathrm{C}^{\prime}\right), 75.1\left(\mathrm{C}^{\prime}\right), 70.3\left(\mathrm{C}^{\prime}\right), 61.4$ $\left(\mathrm{C5}^{\prime}\right)$; HRMS (ESI+) calcd for $\mathrm{C}_{10} \mathrm{H}_{13} \mathrm{~N}_{5} \mathrm{O}_{5}[\mathrm{M}+\mathrm{Na}]^{+}$306.0809, found 306.0810 .

\section{5-Amino-2-[3,5-O-(1,1,3,3-tetraisopropyldisiloxane-1,3-diyl)- $\beta$ - D-ribofuranosyl]-2H-pyrazolo[4,3-d]pyrimidin-7-one (14b)}

Reaction of compound 10b (0.8 g, $2.82 \mathrm{mmol})$, in anhydrous pyridine $(14 \mathrm{~mL})$ under argon atmosphere with 1,3-dichloro1,1,3,3-tetraisopropyldisiloxane $(970 \mu \mathrm{L}, 3.11 \mathrm{mmol})$, was carried out as described for compound 14a and purified by flash column chromatography $\left(\mathrm{CH}_{2} \mathrm{Cl}_{2} / \mathrm{MeOH} 95: 5\right)$ affording compound $14 \mathrm{~b}$ as white solid $(1.1 \mathrm{~g}, 74 \%)$ by ${ }^{1} \mathrm{H}$ NMR $(300 \mathrm{MHz}$, DMSO- $d_{6}$ ): $\delta 10.60$ (br s, $1 \mathrm{H}, \mathrm{NH}$ ), 7.83 (s, 1H, H-9), 5.96 (br s, $2 \mathrm{H}, \mathrm{NH}_{2}$ ), 5.79 (s, $\left.1 \mathrm{H}, \mathrm{H}^{\prime} 1^{\prime}\right), 5.69$ (d, J = 4.4 Hz, 1H, OH), 4.59 (dd, $\left.J=8.2,4.6 \mathrm{~Hz}, 1 \mathrm{H}, \mathrm{H}-3^{\prime}\right), 4.29$ (t, $\left.J=4.4 \mathrm{~Hz}, 1 \mathrm{H}, \mathrm{H}-2^{\prime}\right), 4.03-$ 3.98 (m, 2H, H-4' , H-5a'), 3.90-3.87 (m, 1H, H-5b'), 1.05-0.94 [m, $\left.28 \mathrm{H}, 4 \times \mathrm{CH}\left(\mathrm{CH}_{3}\right)_{2}\right] ;{ }^{13} \mathrm{C}\left(75 \mathrm{MHz}, \mathrm{DMSO}-d_{6}\right): \delta 156.9$ (C7), 150.9 (C5), 139.1 (C3a), 133.9 (C7a), 119.8 (C3), 94.0 (C1'), 80.9 (C4'), $75.8\left(\mathrm{C} 2^{\prime}\right), 70.1\left(\mathrm{C}^{\prime}\right), 60.3\left(\mathrm{C5}^{\prime}\right), 17.3,17.2,17.1,17.1,16.9,16.8$, 13.0, 12.8, 12.7, 12.4, 12.3, $12.2\left[\mathrm{CH}\left(\mathrm{CH}_{3}\right)_{2}\right]$; HRMS (ESI+) calcd for $\mathrm{C}_{22} \mathrm{H}_{40} \mathrm{~N}_{5} \mathrm{O}_{6} \mathrm{Si}_{2}[\mathrm{M}+\mathrm{H}]^{+}$526.2511, found 526.2507.

\section{5-Amino-2-[3,5-O-(1,1,3,3-tetraisopropyldisiloxane-1,3-diyl)-2- deoxy- $\beta$-D-ribofuranosyl]-2H-pyrazolo $[4,3-d]$ pyrimidin-7-one (15b)}

Compound 14b (1.2 g; $2.28 \mathrm{mmol}$ ) was treated with 1,1'-thiocarbonyldiimidazole $(0.406 \mathrm{~g} ; 2.28 \mathrm{mmol})$ in dry $\mathrm{CH}_{2} \mathrm{Cl}_{2}(22 \mathrm{~mL})$ for $8 \mathrm{~h}$ at $35{ }^{\circ} \mathrm{C}$ then with AIBN (75 mg; $0.456 \mathrm{mmol}$ ) and $\mathrm{Bu}_{3} \mathrm{SnH}(1.54 \mathrm{~mL} ; 5.70 \mathrm{mmol})$ in dry toluene $(45 \mathrm{~mL})$, was carried out as described for compound 15a and purified by flash column chromatography ( $1 \%$ to $3 \% \mathrm{MeOH}$ in $\mathrm{CH}_{2} \mathrm{Cl}_{2}$ ). The compound 15b was obtained as white powder $(0.790 \mathrm{~g}, 68 \%$ over two steps). ${ }^{1} \mathrm{H}$ NMR (500 MHz, DMSO- $d_{6}$ ): $\delta 10.83$ (br s, $1 \mathrm{H}, \mathrm{NH}$ ), $7.82(\mathrm{~s}, 1 \mathrm{H}, \mathrm{H}-9), 6.16$ (d, $\left.J=7.3 \mathrm{~Hz}, 1 \mathrm{H}, \mathrm{H}-1^{\prime}\right), 6.13\left(\mathrm{~s}, 2 \mathrm{H}, \mathrm{NH}_{2}\right)$, 4.97 (m, 1H, H-3'), 3.85-3.79 (m, 2H, H-4' $\left.\mathrm{H}^{\prime}-5 \mathrm{a}^{\prime}\right), 3.74$ (dd, $J=$ 12.4, $\left.8.3 \mathrm{~Hz}, 1 \mathrm{H}, \mathrm{H}-5 \mathrm{~b}^{\prime}\right)$, 2.74-2.70 (m, 1H, H-2a'), 2.50-2.45 (m, $\left.1 \mathrm{H}, \mathrm{H}-2 \mathrm{~b}^{\prime}\right), 1.05-0.94\left[\mathrm{~m}, 28 \mathrm{H}, 4 \times \mathrm{CH}\left(\mathrm{CH}_{3}\right)_{2}\right] ;{ }^{13} \mathrm{C}$ NMR $(125$ MHz, DMSO- $d_{6}$ ): $\delta 157.0$ (C7), 151.0 (C5), 139.2 (C3a), 133.6 (C7a), 119.7 (C3), 88.6 (C1'), $84.8\left(\mathrm{C}^{\prime}\right), 72.1\left(\mathrm{C}^{\prime}\right), 63.3\left(\mathrm{C5}^{\prime}\right), 40.1$ $\left(\mathrm{C} 2^{\prime}\right), 17.4,17.3,17.2,17.1,17.0,16.9,16.8,13.1,12.8,12.5,12.3$, $12.0\left[\mathrm{CH}\left(\mathrm{CH}_{3}\right)_{2}\right]$; HRMS (ESI+) calcd for $\mathrm{C}_{22} \mathrm{H}_{40} \mathrm{~N}_{5} \mathrm{O}_{5} \mathrm{Si}_{2}[\mathrm{M}+\mathrm{H}]^{+}$ 510.2562 , found 510.2561 .

\section{5-Amino-2-(2-deoxy- $\beta$-D-ribofuranosyl)-2H-pyrazolo[4,3-d] pyrimidin-7-one (1b)}

Reaction of compound 15b (0.8 g; $1.57 \mathrm{mmol})$ with tetrabutylammonium fluoride in THF $(4.71 \mathrm{~mL}, 4.71 \mathrm{mmol})$ in dry THF (9.4 mL) and was carried out as described for compound $1 \mathrm{a}$ and purified by flash column chromatography $\left(\mathrm{CH}_{2} \mathrm{Cl}_{2} / \mathrm{MeOH} 8: 2\right)$ to yield the product $\mathbf{1 b}$ as white solid $(0.395 \mathrm{~g}, 94 \%) .{ }^{1} \mathrm{H}$ NMR (300 MHz, DMSO- $d_{6}$ ): $\delta 10.38$ (br s, $1 \mathrm{H}, \mathrm{NH}$ ), 7.95 (s, 1H, H-9), $6.14\left(\mathrm{t}, J=4.1 \mathrm{~Hz}, 1 \mathrm{H}, \mathrm{H}-1^{\prime}\right), 5.94\left(\mathrm{br} \mathrm{s}, 2 \mathrm{H}, \mathrm{NH}_{2}\right), 5.28(\mathrm{~d}, J=4.3$ $\mathrm{Hz}, 1 \mathrm{H}, \mathrm{OH}), 4.87$ (t, 1H, J = 5.5 Hz, OH), 4.37-4.34 (m, 1H, H3'), 3.86-3.82 (m, 1H, H-4'), 3.57-3.50 (m, 1H, H-5a'), 3.46-3.40 (m, 1H, H-5b'), 2.62-2.54 (m, 1H, H-2a'), 2.32-2.28 (m, 1H, H$\left.2 \mathrm{~b}^{\prime}\right) ;{ }^{13} \mathrm{C}\left(75 \mathrm{MHz}, \mathrm{DMSO}-d_{6}\right): \delta 157.3$ (C7), 150.9 (C5), 139.2
(C3a), 133.1 (C7a), 119.3 (C3), 90.6 (C1'), 88.1 (C4'), 70.5 (C3'), $61.8\left(\mathrm{C5}^{\prime}\right)$, $40.0\left(\mathrm{C}^{\prime}\right)$; HRMS (ESI+) calcd for $\mathrm{C}_{10} \mathrm{H}_{14} \mathrm{~N}_{5} \mathrm{O}_{4}[\mathrm{M}+$ $\mathrm{H}]^{+}$268.1040, found 268.1055.

\section{2-(2-Deoxy- $\beta$-D-ribofuranosyl)-5-(dimethylaminomethylidene)- $2 H$-pyrazolo[4,3- $d]$ pyrimidin-7-one (16b)}

Reaction of compound $\mathbf{1 b}(0.430 \mathrm{~g}, 1.61 \mathrm{mmol})$ with dimethylformamide dimethyl acetal $(430 \mu \mathrm{L}, 3.22 \mathrm{mmol})$ in $\mathrm{MeOH}$ $(10 \mathrm{~mL})$ was carried out as described for compound 16a and purified by flash column chromatography $\left(\mathrm{CH}_{2} \mathrm{Cl}_{2} / \mathrm{MeOH}\right.$ $95: 5)$ to yield the compound $\mathbf{1 6 b}$ as a white solid (0.50 g, 96\%). ${ }^{1} \mathrm{H}$ NMR (500 MHz, DMSO- $d_{6}$ ): $\delta 11.11$ (br s, $\left.1 \mathrm{H}, \mathrm{NH}\right), 8.54$ (s, $1 \mathrm{H}, \mathrm{N}=\mathrm{CH}), 8.16(\mathrm{~s}, 1 \mathrm{H}, \mathrm{H}-9), 6.19\left(\mathrm{t}, J=6.1 \mathrm{~Hz}, 1 \mathrm{H}, \mathrm{H}-1^{\prime}\right), 5.32$ $(\mathrm{d}, J=4.3 \mathrm{~Hz}, \mathrm{OH}), 4.92(\mathrm{t}, J=5.4 \mathrm{~Hz}, 1 \mathrm{H}, \mathrm{OH}), 4.38(\mathrm{~m}, 1 \mathrm{H}, \mathrm{H}-$ $3^{\prime}$ ), 3.87-3.85 (m, 1H, H-4'), 3.62-3.51 (m, 1H, H-5a'), 3.49-3.40 $\left(\mathrm{m}, 1 \mathrm{H}, \mathrm{H}-5 \mathrm{~b}^{\prime}\right), 3.12\left(\mathrm{~s}, 3 \mathrm{H}, \mathrm{NCH}_{3}\right), 3.00\left(\mathrm{~s}, 3 \mathrm{H}, \mathrm{NCH}_{3}\right), 2.62-2.57$ (m, 1H, H-2a'), 2.34-2.29 (m, 1H, H-2b'); ${ }^{13} \mathrm{C}$ NMR $(125 \mathrm{MHz}$, DMSO- $\left.d_{6}\right): \delta 158.0(\mathrm{~N}=\mathrm{CH}), 157.4(\mathrm{C} 7), 155.1$ (C5), 138.3 (C3a), 134.6 (C7a), 121.0 (C3), 90.7 (C1'), 88.2 (C4'), 70.4 (C3'), 61.7 $\left(\mathrm{C}^{\prime}\right), 40.4\left(\mathrm{NCH}_{3}\right), 39.8\left(\mathrm{C}^{\prime}\right), 34.5\left(\mathrm{NCH}_{3}\right)$; HRMS (ESI+) calcd for $\mathrm{C}_{13} \mathrm{H}_{19} \mathrm{~N}_{6} \mathrm{O}_{4}[\mathrm{M}+\mathrm{H}]^{+}$323.1462, found 323.1455.

2-(5-O-Dimethoxytrityl-2-deoxy- $\beta$-D-ribofuranosyl)-5(dimethylaminomethylidene)-2H-pyrazolo[4,3- $d]$ pyrimidin-7one (17b)

The reaction of compound 16b $(0.450 \mathrm{~g}, 1.4 \mathrm{mmol})$ in dry pyridine (14 mL) and 4,4'-dimethoxytrityl chloride $(0.473 \mathrm{~g}, 1.4$ $\mathrm{mmol}$ ) was carried out as described for compound 17a and purified by flash column chromatography $\left(\mathrm{CH}_{2} \mathrm{Cl}_{2} / \mathrm{MeOH} / \mathrm{TEA}\right.$ $97: 2: 1$ ), affording compound $\mathbf{1 7 b}$ as a white solid (0.665 g, 76\%). ${ }^{1} \mathrm{H}$ NMR (500 MHz, DMSO- $d_{6}$ ): $\delta 11.20$ (br s, $\left.1 \mathrm{H}, \mathrm{NH}\right), 8.53$ (s, 1H, N=CH), 8.12 (s, 1H, H-9), 7.35-7.08 (m, 9H, ArH), 6.80$6.73(\mathrm{~m}, 4 \mathrm{H}, \mathrm{ArH}), 6.26\left(\mathrm{dd}, J=6.7,3.8 \mathrm{~Hz}, 1 \mathrm{H}, \mathrm{H}-1^{\prime}\right), 5.35(\mathrm{~s}, 1 \mathrm{H}$, $\mathrm{OH})$, 4.46-4.43 (m, 1H, H-3'), 4.00-3.84 (m, 1H, H-4'), 3.71 (s, $\left.3 \mathrm{H}, \mathrm{OCH}_{3}\right), 3.69\left(\mathrm{~s}, 3 \mathrm{H}, \mathrm{OCH}_{3}\right), 3.13\left(\mathrm{~s}, 3 \mathrm{H}, \mathrm{NCH}_{3}\right), 3.10-3.04(\mathrm{~m}$, $2 \mathrm{H}, \mathrm{H}-5 \mathrm{a}^{\prime}, \mathrm{b}^{\prime}$ ), 3.01 (s, 3H, $\mathrm{NCH}_{3}$ ), 2.85-2.67 (m, 1H, H-2a'), 2.34$2.30\left(\mathrm{~m}, 1 \mathrm{H}, \mathrm{H}-2 \mathrm{~b}^{\prime}\right) ;{ }^{13} \mathrm{C} \mathrm{NMR}\left(125 \mathrm{MHz}, \mathrm{DMSO}-d_{6}\right): \delta 158.0(\mathrm{~N}=$ $\mathrm{CH}$ ), 157.9, 157.5, 157.4 (Ar, C7), 155.2, 155.1 (Ar, C5), 144.9, 135.7, 135.6, 135.5, 134.7, 134.6 (C7a, C3a, Ar), 129.8, 129.5, 127.7, 126.5, 121.4, 113.1, 91.1 (Ar), 89.9 (C1'), 85.9 (C4'), 85.3 $\left(\mathrm{CPh}_{3}\right), 70.3\left(\mathrm{C3}^{\prime}\right), 63.9\left(\mathrm{C5}^{\prime}\right), 55.0\left(2 \times \mathrm{OCH}_{3}\right), 40.5\left(\mathrm{NCH}_{3}\right), 40.0$ $\left(\mathrm{C2}^{\prime}\right), 39.8\left(\mathrm{NCH}_{3}\right)$; HRMS (ESI + ) calcd for $\mathrm{C}_{34} \mathrm{H}_{37} \mathrm{~N}_{6} \mathrm{O}_{6}[\mathrm{M}+\mathrm{H}]^{+}$ 625.2768 , found 625.2748 .

2-(5-O-Dimethoxytrityl-2-deoxy- $\beta$-D-ribofuranosyl)-5(dimethylaminomethylidene)-2H-pyrazolo[4,3- $d]$ pyrimidin-7one-3-(2-cyanoethyl- $N, N$-diisopropyl)phosphoramidite (18b)

The reaction of compound $\mathbf{1 7 b}(0.250 \mathrm{~g}, 0.40 \mathrm{mmol})$ and $1 \mathrm{M}$ bis(diisopropylamino)(2-cyanoethoxy)phosphine (600 $\mu \mathrm{L}, 0.60$ $\mathrm{mmol})$ and $0.45 \mathrm{M} 1 H$-terazole $(880 \mu \mathrm{L}, 0.440 \mathrm{mmol})$ in anhydrous $\mathrm{CH}_{2} \mathrm{Cl}_{2}(4 \mathrm{~mL})$, was carried out as described for compound 18a and purified by flash column chromatography (hexane/acetone/TEA, $55: 44: 1)$ afforded amidite 18b (0.230 g, $69 \%$ yield). ${ }^{31} \mathrm{P}$ NMR (121 $\left.\mathrm{MHz}, \mathrm{CDCl}_{3}\right) \delta 149.1,148.8$. HRMS $(\mathrm{ESI}+)$ calcd for $\mathrm{C}_{43} \mathrm{H}_{53} \mathrm{~N}_{8} \mathrm{O}_{7} \mathrm{P}[\mathrm{M}+\mathrm{H}]^{+}$825.3847, found 825.3849. 
8-Azido-3'-5'-O-di(tertbutyldimethylsilyl)-2'-deoxyinosine (20a)

To a solution of compound $19(1.0 \mathrm{~g}, 2.08 \mathrm{mmol})$ in dry THF $(40 \mathrm{~mL})$ under argon atmosphere at $-78{ }^{\circ} \mathrm{C}$ was added $n$-BuLi (2.5 $\mathrm{M}$ solution in hexane, $4.2 \mathrm{~mL}, 10.4 \mathrm{mmol}$ ) and the solution was stirred $1 \mathrm{~h}$ at $-78{ }^{\circ} \mathrm{C}$. $p$-Toluenesulfonyl azide $(0.1 \mathrm{M}$ in toluene, $13.7 \mathrm{~mL}, 6.24 \mathrm{mmol}$ ) was added drop wise and the reaction mixture was stirred for $2 \mathrm{~h}$ at $-78{ }^{\circ} \mathrm{C}$ and quenched with $\mathrm{NH}_{4} \mathrm{Cl}$. After removing volatiles, the residue was extracted with $\mathrm{CH}_{2} \mathrm{Cl}_{2}$. The combined organic layers were washed with water, brine and dried over $\mathrm{Na}_{2} \mathrm{SO}_{4}$ and the solvent was removed under reduced pressure and the residue was purified by flash column chromatography $\left(\mathrm{CH}_{2} \mathrm{Cl}_{2} / \mathrm{MeOH} \quad 50 / 1\right)$ to yield compound 20a as light yellow solid (0.65 g, 60\%). ${ }^{1} \mathrm{H}$ NMR (300 $\left.\mathrm{MHz} \mathrm{CDCl}_{3}\right): \delta 13.5(\mathrm{~s}, 1 \mathrm{H}, \mathrm{NH}), 8.02(\mathrm{~s}, 1 \mathrm{H}, \mathrm{H}-2), 6.20(\mathrm{t}, J=6.9$ $\left.\mathrm{Hz}, 1 \mathrm{H}, \mathrm{H}-1^{\prime}\right)$, 4.69-4.74 (m, 1H, H-3'), 3.89-3.92 (m, 1H, H-4'), $3.82\left(\mathrm{dd}, J=10.8,6.5 \mathrm{~Hz}, 1 \mathrm{H}, \mathrm{H}-5 \mathrm{a}^{\prime}\right.$ ), 3.69 (dd, $J=10.8,4.7 \mathrm{~Hz}$, $\left.1 \mathrm{H}, \mathrm{H}-5 \mathrm{~b}^{\prime}\right), 3.25$ (quint, $\left.J=6.8 \mathrm{~Hz}, 1 \mathrm{H}, \mathrm{H}-2 \mathrm{a}^{\prime}\right), 2.14-2.21(\mathrm{~m}, 1 \mathrm{H}$, $\left.\mathrm{H}-2 \mathrm{~b}^{\prime}\right), 0.92\left(\mathrm{~s}, 9 \mathrm{H}, \mathrm{CCH}_{3}\right), 0.86\left(\mathrm{~s}, 9 \mathrm{H}, \mathrm{CCH}_{3}\right), 0.12\left(\mathrm{~s}, 6 \mathrm{H}, \mathrm{SiCH}_{3}\right)$, 0.019 (s, 3H, $\left.\mathrm{SiCH}_{3}\right),-0.006\left(\mathrm{~s}, 3 \mathrm{H}, \mathrm{SiCH}_{3}\right) ;{ }^{13} \mathrm{C}-\mathrm{NMR}(75 \mathrm{MHz}$, $\mathrm{CDCl}_{3}$ ): $\delta 158.4$ (C6), 149.3, 145.7, 143.7 (C4, C8, C2), 123.1 (C5), 87.9, 83.7 (C4', C1'), $72.3\left(\mathrm{C}^{\prime}\right), 62.8\left(\mathrm{C}^{\prime}\right), 37.4\left(\mathrm{C}^{\prime}\right), 26.0,25.9$ $\left(\mathrm{CH}_{3}\right), 18.5,18.1\left(\mathrm{CCH}_{3}\right),-4.5,-4.6,-5.2,-5.3\left(\mathrm{SiCH}_{3}\right)$. HRMS: calcd for $\mathrm{C}_{22} \mathrm{H}_{40} \mathrm{~N}_{7} \mathrm{O}_{4} \mathrm{Si}_{2}[\mathrm{M}+\mathrm{H}]^{+} 522.2675$, found 522.2682 .

\section{8-Amino- $N^{8}$-(dimethylaminomethylidene) $-3^{\prime}-5^{\prime}-O$ - di(tertbutyldimethylsilyl)-2' -deoxyinosine (21a)}

To a pre-cooled solution of compound 20a (600 $\mathrm{mg}, 1.15 \mathrm{mmol})$ in $\mathrm{MeOH}(6 \mathrm{~mL})$ was added $\mathrm{NaBH}_{4}(0.218 \mathrm{~g}, 5.75 \mathrm{mmol})$ portion wise at $0{ }^{\circ} \mathrm{C}$. The reaction mixture was allowed to warm to room temperature and stirred for $2 \mathrm{~h}$. After the completion of the reaction, excess $\mathrm{NaBH}_{4}$ was carefully quenched with saturated $\mathrm{NH}_{4} \mathrm{Cl}(2 \mathrm{~mL})$ and the solvents were removed under reduced pressure. The crude product was used without further purification for the next step. The solution of crude product in $\mathrm{N}, \mathrm{N}$ dimethylforamide-dimethylacetal $(5 \mathrm{~mL})$ was heated at $70{ }^{\circ} \mathrm{C}$ for $1 \mathrm{~h}$. After removing solvent, the crude residue was purified by flash column chromatography $\left(\mathrm{CH}_{2} \mathrm{Cl}_{2} / \mathrm{MeOH} 30 / 1\right)$ to yield compound 21a (448 mg, 70\%) as light yellow solid. ${ }^{1} \mathrm{H}$ NMR (300 $\left.\mathrm{MHz} \mathrm{CDCl}_{3}\right): \delta 13.4(\mathrm{~s}, 1 \mathrm{H}, \mathrm{NH}), 8.71(\mathrm{~s}, 1 \mathrm{H}, \mathrm{N}=\mathrm{CH}), 7.75(\mathrm{~s}$, $1 \mathrm{H}, \mathrm{H}-2), 6.64\left(\mathrm{t}, J=7.3 \mathrm{~Hz}, 1 \mathrm{H}, \mathrm{H}-1^{\prime}\right), 4.71-4.72\left(\mathrm{~m}, 1 \mathrm{H}, \mathrm{H}-3^{\prime}\right)$, 3.83-3.92 (m, 2H, H-4', H-5a'), 3.68 (dd, $J=4.2,9.7 \mathrm{~Hz}, 1 \mathrm{H}, \mathrm{H}-$ $5 \mathrm{~b}^{\prime}$ ), 3.39 (quint, $\left.J=5.9 \mathrm{~Hz}, 1 \mathrm{H}, \mathrm{H}-2 \mathrm{a}^{\prime}\right), 2.08-2.15\left(\mathrm{~m}, 1 \mathrm{H}, \mathrm{H}-2 \mathrm{~b}^{\prime}\right)$, $0.91\left(\mathrm{~s}, 9 \mathrm{H}, \mathrm{CCH}_{3}\right), 0.86\left(\mathrm{~s}, 9 \mathrm{H}, \mathrm{CCH}_{3}\right), 0.10\left(\mathrm{~s}, 6 \mathrm{H}, \mathrm{SiCH}_{3}\right),-0.01$ (s, 3H, $\left.\mathrm{SiCH}_{3}\right),-0.02$ (s, 3H, $\left.\mathrm{SiCH}_{3}\right) ;{ }^{13} \mathrm{C}-\mathrm{NMR}\left(75 \mathrm{MHz}, \mathrm{CDCl}_{3}\right)$ : $\delta$ 158.7, 157.6, 155.8, 148.7, $141.6(\mathrm{C} 6, \mathrm{C}=\mathrm{N}, \mathrm{C} 2, \mathrm{C} 8, \mathrm{C} 4), 123.1$ (C5), 87.4, $83.1\left(\mathrm{C1}^{\prime}, \mathrm{C}^{\prime}\right), 73.2\left(\mathrm{C3}^{\prime}\right), 63.4\left(\mathrm{C5}^{\prime}\right), 40.9\left(\mathrm{NCH}_{3}\right), 36.9$ $\left(\mathrm{C} 2^{\prime}\right), 34.8\left(\mathrm{NCH}_{3}\right), 26.0,25.9\left(\mathrm{CH}_{3}\right), 18.5,18.1\left(\mathrm{CCH}_{3}\right),-4.5$, $-5.1,-5.2\left(\mathrm{SiCH}_{3}\right)$. HRMS: calcd for $\mathrm{C}_{25} \mathrm{H}_{47} \mathrm{~N}_{6} \mathrm{O}_{4} \mathrm{Si}_{2}[\mathrm{M}+\mathrm{H}]^{+}$ 551.3191 , found 551.3198.

\section{8-Amino- $\boldsymbol{N}^{8}$-(dimethylaminomethylidene)-2' -deoxyinosine} (22a)

To a solution of compound $21 \mathrm{a}(0.55 \mathrm{~g}, 1.0 \mathrm{mmol})$ in THF (10 $\mathrm{mL}$ ) was added TBAF ( $1 \mathrm{M}$ in THF, $2.2 \mathrm{~mL}, 2.2 \mathrm{mmol}$ ) and the solution was stirred overnight at room temperature. After removing volatiles, the crude residue was purified by flash column chromatography $\left(\mathrm{CH}_{2} \mathrm{Cl}_{2} / \mathrm{MeOH} 20 / 1\right)$ to yield compound 22a $(0.19 \mathrm{~g}, 60 \%)$ as a white solid. ${ }^{1} \mathrm{H}$ NMR (300 MHz, DMSO- $\left.d_{6}\right): \delta 8.56(\mathrm{~s}, 1 \mathrm{H}, \mathrm{N}=\mathrm{CH}), 7.82(\mathrm{~s}, 1 \mathrm{H}, \mathrm{H}-2), 6.50(\mathrm{t}$, $\left.J=6.4 \mathrm{~Hz}, 1 \mathrm{H}, \mathrm{H}-1^{\prime}\right), 4.41-4.42\left(\mathrm{~m}, 1 \mathrm{H}, \mathrm{H}-3^{\prime}\right), 3.82(\mathrm{br} \mathrm{s}, 1 \mathrm{H}, \mathrm{H}-$ $4^{\prime}$ ), 3.64 (dd, $J=11.8,4.2 \mathrm{~Hz}, 1 \mathrm{H}, \mathrm{H}-5 \mathrm{a}^{\prime}$ ), 3.48 (dd, $J=11.7,4.3$ $\mathrm{Hz}, 1 \mathrm{H}, \mathrm{H}-5 \mathrm{~b}^{\prime}$ ), 3.14 (s, 3H, $\mathrm{NCH}_{3}$ ), 3.02 (s, 4H, $\mathrm{NCH}_{3}, \mathrm{H}-2 \mathrm{a}^{\prime}$ ), 1.98-2.05 (m, $\left.1 \mathrm{H}, \mathrm{H}-2 \mathrm{~b}^{\prime}\right) ;{ }^{13} \mathrm{C}-\mathrm{NMR}$ (75 MHz, DMSO- $\left.d_{6}\right): \delta 159.0$, 156.8, 153.0, 147.3, 145.1 (C6, C=N, C2, C8, C4), 122.3 (C5), 87.7, 82.8 ( $\left.\mathrm{C}^{\prime}, \mathrm{C}^{\prime}\right), 71.6\left(\mathrm{C3}^{\prime}\right), 62.5\left(\mathrm{C5}^{\prime}\right), 40.2\left(\mathrm{NCH}_{3}\right), 37.4$ $\left(\mathrm{C}^{\prime}\right), 34.2\left(\mathrm{NCH}_{3}\right)$. HRMS: calcd for $\mathrm{C}_{13} \mathrm{H}_{19} \mathrm{~N}_{6} \mathrm{O}_{4}[\mathrm{M}+\mathrm{H}]^{+}$ 323.1462, found 323.1474.

\section{8-Amino- $\mathrm{N}^{8}$-(dimethylaminomethylidene)-5 $\mathbf{5}^{\prime}-\mathrm{O}$ - dimethoxytrityl-2' -deoxyinosine (23a)}

Reaction of compound 22a $(0.16 \mathrm{~g}, 0.50 \mathrm{mmol})$ with $4,4^{\prime}$-dimethoxytrityl chloride $(0.168 \mathrm{~g}, 0.50 \mathrm{mmol})$ in dry pyridine/DMF $(16 \mathrm{~mL}, 7 / 1 \mathrm{v} / \mathrm{v})$ was carried out as described for compound 17a and purified by flash column chromatography $\left(\mathrm{CH}_{2} \mathrm{Cl}_{2} / \mathrm{MeOH} /\right.$ TEA 80/2/1) to yield compound 23a (0.3 g, 96\%) as white solid. ${ }^{1} \mathrm{H}$ NMR (500 MHz, DMSO- $\left.d_{6}\right): \delta 8.53(\mathrm{~s}, 1 \mathrm{H}, \mathrm{N}=\mathrm{CH}), 7.93(\mathrm{~s}, 1 \mathrm{H}$, $\mathrm{H}-2$ ), 7.27 (d, J=7.3 Hz, 2H, ArH), 7.30-7.27 (m, 8H, ArH), 6.85$6.74(\mathrm{~m}, 4 \mathrm{H}, \mathrm{ArH}), 6.52\left(\mathrm{t}, J=7.2 \mathrm{~Hz}, 1 \mathrm{H}, \mathrm{H}-1^{\prime}\right), 5.25(\mathrm{~d}, J=5.25$ $\mathrm{Hz}, \mathrm{OH}), 4.47-4.43$ (m, 1H, H-3'), 3.97-3.70 (m, 1H, H-4'), 3.72 $\left(\mathrm{s}, 3 \mathrm{H}, \mathrm{OCH}_{3}\right), 3.71\left(\mathrm{~s}, 3 \mathrm{H}, \mathrm{OCH}_{3}\right), 3.451-3.26\left(\mathrm{~m}, 2 \mathrm{H}, \mathrm{H}-\mathrm{H}-5^{\prime}\right)$, 3.14-3.09 (m, 4H, $\left.\mathrm{CH}_{3}, \mathrm{H}-2 \mathrm{a}^{\prime}\right), 2.94$ (s, 3H, $\mathrm{NCH}_{3}$ ), 2.14-2.06 (m, $\left.1 \mathrm{H}, \mathrm{H}-2 \mathrm{~b}^{\prime}\right) .{ }^{13} \mathrm{C}$ NMR $\left(125 \mathrm{MHz}, \mathrm{DMSO}-d_{6}\right) \delta 158.3,157.4,156.0$, 154.9 (Ar, C6, C=N, C2, C8, C4), 147.0, 145.5, 136.2, 136.1, 130.1, 130.0, 128.0, 127.9, 126.8 (Ar), 122.0 (C5), 113.3, 113.3 (Ar), 86.0, 85.6 [C1', C( $\left.\left.\mathrm{CH}_{3}\right)_{3}\right], 82.5\left(\mathrm{C}^{\prime}\right), 71.8\left(\mathrm{C}^{\prime}\right), 64.9\left(\mathrm{C5}^{\prime}\right)$, $55.4\left(\mathrm{OCH}_{3}\right), 36.9,34.7,33.7\left(2 \mathrm{NCH}_{3}, \mathrm{C} 2^{\prime}\right)$. HRMS: calcd for $\mathrm{C}_{34} \mathrm{H}_{37} \mathrm{~N}_{6} \mathrm{O}_{6}[\mathrm{M}+\mathrm{H}]^{+}$625.2769, found 625.2770.

\section{8-Amino- $N^{8}$-(dimethylaminomethylidene)- $5^{\prime}-O$ -} dimethoxytrityl-2'-deoxyinosine-3' - (2-cyanoethyl- $N, N$ diisopropyl)-phosphoramidite (24a)

Reaction of compound 23a $(0.2 \mathrm{~g}, 0.32 \mathrm{mmol})$ with $1 \mathrm{M}$ bis (diisopropylamino)(2-cyanoethoxy)phosphine (1 $\mathrm{M}$ in $\mathrm{CH}_{3} \mathrm{CN}$, $0.96 \mathrm{~mL}, 0.96 \mathrm{mmol})$ and $1 \mathrm{H}$-tetrazole $\left(0.45 \mathrm{M}\right.$ in $\mathrm{CH}_{3} \mathrm{CN}, 1.56$ $\mathrm{mL}, 0.70 \mathrm{mmol})$ in anhydrous $\mathrm{CH}_{2} \mathrm{Cl}_{2}(10 \mathrm{~mL})$, was carried out as described for compound $\mathbf{1 8 a}$ and purified by flash column chromatography $\left(\mathrm{CH}_{2} \mathrm{Cl}_{2} / \mathrm{MeOH} / \mathrm{TEA} 80 / 2 / 1\right)$ to yield compound 24a $(0.20 \mathrm{~g}, 75 \%)$ as white solid. ${ }^{31} \mathrm{P} \mathrm{NMR}\left(121 \mathrm{MHz}, \mathrm{CDCl}_{3}\right)$ $\delta$ 148.5, 148.0. HRMS: calcd for $\mathrm{C}_{13} \mathrm{H}_{19} \mathrm{~N}_{6} \mathrm{O}_{4}[\mathrm{M}+\mathrm{H}]^{+} 323.1462$, found 323.1474.

\section{8-Azido-3'-5' -O-di(tertbutyldimethylsilyl)- $N^{1}$-methyl-2' - deoxyinosine (20b)}

To a solution of sodium hydride $(344 \mathrm{mg}, 8.62 \mathrm{mmol})$ in dry THF (30 mL), compound 20a (3.0 g, $5.75 \mathrm{mmol})$ in THF (50 mL) was added drop wise at $0{ }^{\circ} \mathrm{C}$ and stirred for $15 \mathrm{~min}$. Methyl iodide $(0.72 \mathrm{~mL}, 11.50 \mathrm{mmol})$ was added slowly to the reaction mixture at $0{ }^{\circ} \mathrm{C}$. The reaction mixture was stirred at room temperature for $12 \mathrm{~h}$ and then $\mathrm{NH}_{4} \mathrm{Cl}(5 \mathrm{~mL})$ was added to the reaction mixture to quench the excess sodium hydride and the reaction mixture was 
evaporated to dryness. The residue obtained was extracted with $\mathrm{CH}_{2} \mathrm{Cl}_{2}(2 \times 100 \mathrm{~mL})$, washed with water $(2 \times 15 \mathrm{~mL})$, brine $(10$ $\mathrm{mL}$ ) and dried over anhydrous $\mathrm{Na}_{2} \mathrm{SO}_{4}$ and the solvent was removed under reduced pressure and the residue was purified by flash column chromatography ( $n$-hexane/ethyl acetate $7 / 3$ ) to yield compound $20 \mathrm{~b}$ as a yellow solid $(2.71 \mathrm{~g}, 88 \%) .{ }^{1} \mathrm{H}$ NMR (500 $\mathrm{MHz}_{\mathrm{CDCl}}$ ) $\delta 7.87(\mathrm{~s}, 1 \mathrm{H}, \mathrm{H}-2), 6.16\left(\mathrm{t}, J=6.9 \mathrm{~Hz}, 1 \mathrm{H}, \mathrm{H}-1^{\prime}\right)$, 4.74-4.69 (m, 1H, H-3'), 3.90-3.86 (m, 1H, H-4'), 3.79 (dd, $J=$ 10.9, $6.4 \mathrm{~Hz}, 1 \mathrm{H}, \mathrm{H}-5 \mathrm{~b}^{\prime}$ ), 3.68 (dd, $\left.J=10.9,4.6 \mathrm{~Hz}, 1 \mathrm{H}, \mathrm{H}-5 \mathrm{a}^{\prime}\right), 3.63$ (s, 3H, $\mathrm{NCH}_{3}$ ), 3.18 (pent, $J=6.9 \mathrm{~Hz}, 1 \mathrm{H}, \mathrm{H}-2 \mathrm{~b}^{\prime}$ ), 2.15 (ddd, $J=$ 10.8, 6.9, 3.9 Hz, 1H, H-2a'), 0.92 (s, 9H, $\left.\mathrm{CCH}_{3}\right), 0.85$ (s, 9H, $\left.\mathrm{CCH}_{3}\right), 0.11\left(\mathrm{~s}, 6 \mathrm{H}, \mathrm{SiCH}_{3}\right), 0.02\left(\mathrm{~s}, 3 \mathrm{H}, \mathrm{SiCH}_{3}\right),-0.01(\mathrm{~s}, 3 \mathrm{H}$, $\left.\mathrm{SiCH}_{3}\right) ;{ }^{13} \mathrm{C} \mathrm{NMR}\left(125 \mathrm{MHz}, \mathrm{CDCl}_{3}\right.$ ) $\delta 156.1$ (C6), 147.7 (C4), 146.0 (C2), 145.1 (C8), 122.9 (C5), 87.6 (C4'), 83.4 (C1'), 72.1 (C3'), 62.7 $\left(\mathrm{C}^{\prime}\right), 37.3\left(\mathrm{C2}^{\prime}\right), 34.4\left(\mathrm{NCH}_{3}\right), 26.0,25.9\left(\mathrm{CCH}_{3}\right), 18.4,18.1\left(\mathrm{CH}_{3} \mathrm{C}\right)$, $-4.5,-4.6,-5.2,-5.3\left(\mathrm{CH}_{3} \mathrm{Si}\right)$; HRMS (ESI+): calcd for $\mathrm{C}_{23} \mathrm{H}_{41} \mathrm{~N}_{7} \mathrm{O}_{4} \mathrm{Si}_{2}[\mathrm{M}+\mathrm{H}]^{+}$536.2831; found 536.2832.

\section{8-Amino- $N^{8}$-(dimethylaminomethylidene)- $3^{\prime}-5^{\prime}-O$ - di(tertbutyldimethylsilyl)- $N^{1}$-methyl-2' -deoxy-inosine (21b)}

The reaction of compound $20 \mathrm{~b}(2.5 \mathrm{~g}, 4.67 \mathrm{mmol})$ with $\mathrm{NaBH}_{4}$ (882 $\mathrm{mg}, 23.33 \mathrm{mmol}$ ) in $\mathrm{MeOH}(26 \mathrm{~mL})$ and then with $N, N$ dimethylformamide-dimethylacetal $(15 \mathrm{~mL})$ was carried out as described for compound 21a, and purified by flash column chromatography $\left(\mathrm{CH}_{2} \mathrm{Cl}_{2} / \mathrm{MeOH} 15 / 1\right)$ to yield yellow solid (1.92 g, 73\%). ${ }^{1} \mathrm{H}$ NMR (500 MHz, DMSO- $\left.d_{6}\right) \delta 8.56(\mathrm{~s}, 1 \mathrm{H}, \mathrm{CH}=\mathrm{N})$, 8.18 (s, 1H, H-2), 6.47 (t, $\left.J=7.0 \mathrm{~Hz}, 1 \mathrm{H}, \mathrm{H}-1^{\prime}\right), 4.71$ (dt, $J=6.7$, $3.6 \mathrm{~Hz}, 1 \mathrm{H}, \mathrm{H}-3^{\prime}$ ), 3.80 (dd, $J=10.4,6.7 \mathrm{~Hz}, 1 \mathrm{H}, \mathrm{H}-5 \mathrm{~b}^{\prime}$ ), 3.77-3.72 (m, $\left.1 \mathrm{H}, \mathrm{H}-4^{\prime}\right), 3.59$ (dd, $\left.J=10.4,4.9,1 \mathrm{H}, \mathrm{H}-5 \mathrm{a}^{\prime}\right), 3.47(\mathrm{~s}, 3 \mathrm{H}$, $\mathrm{NCH}_{3}$ ), 3.28-3.21 (m, 1H, H-2b'), 3.15 (s, 3H, $\mathrm{NCH}_{3}$ ), 3.02 (s, 3H, $\mathrm{NCH}_{3}$ ), 2.09 (ddd, $J=10.9,7.0,3.6 \mathrm{~Hz}, 1 \mathrm{H}, \mathrm{H}-2 \mathrm{a}^{\prime}$ ), 0.90 (s, 9H, $\left.\mathrm{CCH}_{3}\right) 0.83\left(\mathrm{~s}, 9 \mathrm{H}, \mathrm{CCH}_{3}\right), 0.11\left(\mathrm{~s}, 6 \mathrm{H}, \mathrm{SiCH}_{3}\right),-0.01(\mathrm{~s}, 3 \mathrm{H}$, $\left.\mathrm{SiCH}_{3}\right),-0.03\left(\mathrm{~s}, 3 \mathrm{H}, \mathrm{SiCH}_{3}\right) .{ }^{13} \mathrm{C}$ NMR (125 MHz, DMSO- $\left.d_{6}\right)$ $\delta 157.1(\mathrm{C}=\mathrm{N}), 155.7$ (C6), 154.6 (C4), 146.8 (C8), 145.5 (C2), 121.7 (C5), $86.3\left(\mathrm{C}^{\prime}\right), 81.9\left(\mathrm{C}^{\prime}\right), 72.5\left(\mathrm{C}^{\prime}\right), 62.8\left(\mathrm{C5}^{\prime}\right), 40.2$ $\left(\mathrm{NCH}_{3}\right), 36.2\left(\mathrm{C}^{\prime}\right), 34.3\left(\mathrm{NCH}_{3}\right), 33.4\left(\mathrm{NCH}_{3}\right), 25.7\left(\mathrm{CH}_{3}\right), 18.0$ $\left(\mathrm{CCH}_{3}\right), 17.7\left(\mathrm{CCH}_{3}\right),-4.6\left(\mathrm{SiCH}_{3}\right),-4.7\left(\mathrm{SiCH}_{3}\right)$. HRMS (ESI+): calcd for $\mathrm{C}_{23} \mathrm{H}_{43} \mathrm{~N}_{5} \mathrm{O}_{4} \mathrm{Si}_{2}[\mathrm{M}+\mathrm{H}]^{+}$565.3348; found 565.3358.

\section{8-Amino- $N^{8}$-(dimethylaminomethylidene)- $N^{\mathbf{1}}$-methyl-2' deoxyinosine (22b)}

The reaction of compound $21 \mathrm{~b}(565 \mathrm{mg}, 1.0 \mathrm{mmol})$ with TBAF (1 $\mathrm{M}$ in THF, $2.2 \mathrm{~mL}, 2.2 \mathrm{mmol})$ in THF (10 mL) was carried out as described for compound 22a and purified by flash column chromatography $\left(\mathrm{CH}_{2} \mathrm{CI}_{2} / \mathrm{MeOH}, 9: 1\right)$ to give 22b $(246 \mathrm{mg}$, $73 \%)$ as a pale yellow solid. ${ }^{1} \mathrm{H}$ NMR $\left(500 \mathrm{MHz}\right.$, DMSO- $\left.d_{6}\right) \delta 8.56$ $(\mathrm{s}, 1 \mathrm{H}, \mathrm{CH}=\mathrm{N}), 8.21(\mathrm{~s}, 1 \mathrm{H}, \mathrm{H}-2), 6.49\left(\mathrm{t}, J=6.4 \mathrm{~Hz}, 1 \mathrm{H}, \mathrm{H}-1^{\prime}\right)$, 5.25 (s, 1H, OH), 4.96 (s, 1H, OH), 4.43 (br s, 1H, H-3'), 3.81 (br s, $1 \mathrm{H}, \mathrm{H}-4^{\prime}$ ), 3.64 (dd, $J=11.4,4.6 \mathrm{~Hz}, 1 \mathrm{H}, \mathrm{H}-5 \mathrm{~b}^{\prime}$ ), 3.47 (br s, $4 \mathrm{H}$, $\mathrm{NCH}_{3}, \mathrm{H}-5 \mathrm{a}^{\prime}$ ), 3.14 (s, 3H, $\mathrm{NCH}_{3}$ ), 3.09-2.90 (m, 4H, $\mathrm{NCH}_{3}, \mathrm{H}-$ $2 \mathrm{~b}^{\prime}$ ), 2.05 (ddd, $\left.J=8.8,6.4,2.0 \mathrm{~Hz}, 1 \mathrm{H}, \mathrm{H}-2 \mathrm{a}^{\prime}\right) ;{ }^{13} \mathrm{C}$ NMR $(125$ $\left.\mathrm{MHz}, \mathrm{DMSO}-d_{6}\right) \delta 157.1(\mathrm{C}=\mathrm{N}), 155.5$ (C6), $154.4(\mathrm{C} 8), 146.5$ (C4), 145.6 (C2), 121.7 (C5), $87.5\left(\mathrm{C}^{\prime}\right), 82.5\left(\mathrm{C}^{\prime}\right), 71.3\left(\mathrm{C}^{\prime}\right), 62.3$ $\left(\mathrm{C5}^{\prime}\right), 40.3\left(\mathrm{NCH}_{3}\right), 37.1\left(\mathrm{NCH}_{3}\right), 34.4\left(\mathrm{C}^{\prime}\right), 33.4\left(\mathrm{NCH}_{3}\right)$; HRMS (ESI+): calcd for $\mathrm{C}_{14} \mathrm{H}_{20} \mathrm{~N}_{6} \mathrm{O}_{4}[\mathrm{M}+\mathrm{Na}]^{+} 359.1438$; found 359.1444 .
8-Amino- $N^{8}$-(dimethylaminomethylidene) $-5^{\prime}-O$ dimethoxytrityl- $N^{1}$-methyl-2'-deoxyinosine (23b)

Reaction of 22b (420 mg, $1.25 \mathrm{mmol}$ ) with 4,4'-dimethoxytrityl chloride (465 mg, $1.37 \mathrm{mmol}$ ) in dry pyridine $(45 \mathrm{~mL})$, in dry $\mathrm{CH}_{2} \mathrm{Cl}_{2}(5 \mathrm{~mL})$ was carried out as described for compound 17a and purified by flash column chromatography $\left(\mathrm{CH}_{2} \mathrm{Cl}_{2} / \mathrm{MeOH} /\right.$ TEA $80 / 2 / 1)$ to yield compound $23 \mathbf{b}(710 \mathrm{mg}, 89 \%)$ as white solid. ${ }^{1} \mathrm{H}$ NMR $\left(500 \mathrm{MHz}, \mathrm{CDCl}_{3}\right) \delta 8.68(\mathrm{~s}, 1 \mathrm{H}, \mathrm{N}=\mathrm{CH}), 7.45(\mathrm{~s}$, $1 \mathrm{H}, \mathrm{H}-2), 7.41$ (d, J = 7.2 Hz, 2H, Ar), 7.31-7.15 (m, 7H, Ar), 6.78$6.73(\mathrm{~m}, 4 \mathrm{H}, \mathrm{Ar}), 6.66\left(\mathrm{t}, J=6.9 \mathrm{~Hz}, 1 \mathrm{H}, \mathrm{H}-1^{\prime}\right), 4.85-4.80(\mathrm{~m}, 1 \mathrm{H}$, $\left.\mathrm{H}-3^{\prime}\right)$, 4.11-4.06 (m, $\left.1 \mathrm{H}, \mathrm{H}-4^{\prime}\right), 3.77\left(\mathrm{~s}, 3 \mathrm{H}, \mathrm{OCH}_{3}\right), 3.76(\mathrm{~s}, 3 \mathrm{H}$, $\mathrm{OCH}_{3}$ ), 3.54 (s, $3 \mathrm{H}, \mathrm{NCH}_{3}$ ), 3.52-3.45 (m, 1H, H-5b'), 3.32-3.25 (m, $\left.2 \mathrm{H}, \mathrm{H}-2 \mathrm{~b}^{\prime}, \mathrm{H}-5 \mathrm{~b}^{\prime}\right), 3.07$ (m, 3H, $\left.\mathrm{NCH}_{3}\right), 3.02\left(\mathrm{~m}, 3 \mathrm{H}, \mathrm{NCH}_{3}\right.$ ), 2.28 (ddd, $\left.J=12.3,6.9,4.5 \mathrm{~Hz}, 1 \mathrm{H}, \mathrm{H}-2 \mathrm{a}^{\prime}\right) ;{ }^{13} \mathrm{C}$ NMR $(125 \mathrm{MHz}$, $\left.\mathrm{CDCl}_{3}\right) \delta 158.5(\mathrm{Ar}), 157.5(\mathrm{~N}=\mathrm{C}), 156.7$ (C6), 155.4 (C8), 146.9 (C4), 145.0 (Ar), 143.7 (C2), 136.3, 136.1, 130.2, 128.2, 127.8, 126.7 (Ar), 122.8 (C5), 113.1 (Ar), $86.3\left(\mathrm{CPh}_{3}\right), 85.5\left(\mathrm{C} 4^{\prime}\right), 82.6$ $\left(\mathrm{C1}^{\prime}\right)$, $73.6\left(\mathrm{C3}^{\prime}\right), 64.6\left(\mathrm{C5}^{\prime}\right), 55.3\left(\mathrm{OCH}_{3}\right), 40.9\left(\mathrm{NCH}_{3}\right), 37.2\left(\mathrm{C2}^{\prime}\right)$, 34.8, $34.1\left(\mathrm{NCH}_{3}\right)$; HRMS (ESI+): calcd for $\mathrm{C}_{35} \mathrm{H}_{38} \mathrm{~N}_{6} \mathrm{O}_{6}[\mathrm{M}+\mathrm{H}]^{+}$ 639.2925 ; found 639.2926 .

\section{8-Amino- $\boldsymbol{N}^{8}$-(dimethylaminomethylidene) $-5^{\prime}-O$ - dimethoxytrityl- $N^{1}$-methyl-2'-deoxyinosine-3' -(2-cyanoethyl- $N, N$-diisopropyl)phosphoramidite (24b)}

The reaction of compound $23 \mathbf{b}$ with $1 \mathrm{M}$ bis(diisopropylamino)(2-cyanoethoxy)phosphine $(1.18 \mathrm{~mL}, 1.40 \mathrm{mmol}$ ) and 0.45 M $1 H$-tetrazole $(1.45 \mathrm{~mL}, 0.77 \mathrm{mmol})$ in $\mathrm{CH}_{2} \mathrm{Cl}_{2}(25 \mathrm{~mL})$ was carried out as described for compound 18a and purified by flash column chromatography $\left(\mathrm{CH}_{2} \mathrm{Cl}_{2} / \mathrm{MeOH} / \mathrm{TEA} 40 / 1 / 1\right)$ to yield compound 24b (0.380 g, 77\%) as white solid. ${ }^{31} \mathrm{P}$ NMR (202 MHz, $\left.\mathrm{CDCl}_{3}\right) \delta$ 148.6, 148.2. HRMS (ESI+): calcd for $\mathrm{C}_{44} \mathrm{H}_{55} \mathrm{~N}_{8} \mathrm{O}_{7} \mathrm{P}[\mathrm{M}+$ $\mathrm{H}]^{+}$839.4003; found 839.4014.

\section{7,8-Dihydro-8-oxo-2'-deoxyinosine $(3)^{29}$}

A solution of $\mathrm{NaNO}_{2}(516 \mathrm{mg}, 7.48 \mathrm{mmol})$ in $(2 \mathrm{~mL})$ of water was added to a stirred solution of $1 \mathrm{~g}$ ( $3.74 \mathrm{mmol})$ of compound 5 in $50 \mathrm{~mL}$ of $95 \%$ aqueous acetic acid. The reaction mixture was stirred overnight. The solvent was removed under reduced pressure and the oily residue was purified by flash column chromatography $\left(\mathrm{CH}_{2} \mathrm{CI}_{2} / \mathrm{MeOH}, 4: 1\right)$ to give 3 (780 mg, 77\%) as a white solid. Spectral and analytical data were in agreement with previous report. ${ }^{29}$

\section{7,8-Dihydro-5' -O-dimethoxytrityl-8-oxo-2'-deoxyinosine $(25)^{29}$}

Reaction of compound 3 (350 mg, $1.35 \mathrm{mmol}$ ) with 4,4'-dimethoxytrityl chloride ( $486 \mathrm{mg}, 1.44 \mathrm{mmol})$ in dry pyridine $(70 \mathrm{~mL})$ was carried out as described for compound $17 \mathbf{a}$ and purified by flash column chromatography $\left(\mathrm{CH}_{2} \mathrm{CI}_{2} / \mathrm{MeOH} / \mathrm{TEA}, 95: 4: 1\right)$ to give $25(510 \mathrm{mg}, 69 \%)$ as a white foam. Spectral and analytical data were in agreement with previous report. ${ }^{29}$

\section{7,8-Dihydro-5'-O-dimethoxytrityl-8-oxo-2' - deoxyinosine-3' (2-cyanoethyl- $N, N$-diisopropyl)phosphoramidite $(26)^{29}$}

The reaction of compound 25 (400 $\mathrm{mg}, 0.70 \mathrm{mmol})$ with $1 \mathrm{M}$ bis(diisopropylamino)(2-cyanoethoxy)phosphine (1.40 mL, 1.40 
$\mathrm{mmol}$ ) and $0.45 \mathrm{M} 1 \mathrm{H}$-tetrazole $(1.7 \mathrm{~mL}, 0.77 \mathrm{mmol})$ in $\mathrm{CH}_{2} \mathrm{Cl}_{2}$ (25 mL) was carried out as described for compound 18a and purified by flash column chromatography ( $n$-hexane/acetone/ TEA, 39:60:1) to give $26(430 \mathrm{mg}, 80 \%)$ as a white foam. Spectral and analytical data were in agreement with previous report. $^{29}$

\section{7,8-Dihydro- $N^{6}$-(dimethylaminomethylidene)-8-oxo-2' deoxyadenosine (27)}

To a suspension of compound 5 ( $1 \mathrm{~g}, 3.74 \mathrm{mmol})$ in $\mathrm{MeOH}$ (35 $\mathrm{mL}), N, N$-dimethylformamide dimethyl acetal $(2.5 \mathrm{~mL}, 18.7$ mmol) was added. The reaction mixture was stirred at $65{ }^{\circ} \mathrm{C}$ for $3 \mathrm{~h}$. The reaction mixture was evaporated to dryness and purified by flash column chromatography $\left(\mathrm{CH}_{2} \mathrm{Cl}_{2} / \mathrm{MeOH}\right.$ : TEA, $90: 9: 1)$ to give $27(1.1 \mathrm{~g}, 91 \%)$ as a white solid. ${ }^{1} \mathrm{H}$ NMR (500 $\left.\mathrm{MHz}, \mathrm{DMSO}-d_{6}\right) \delta 8.72(\mathrm{~s}, 1 \mathrm{H}, \mathrm{HC}=\mathrm{N}), 8.19(\mathrm{~s}, 1 \mathrm{H}, \mathrm{H}-2), 6.17$ (dd, $\left.\left.J=8.2,6.5 \mathrm{~Hz}, 1 \mathrm{H}, \mathrm{H}^{\prime}\right)^{\prime}\right), 5.20(\mathrm{~s}, 1 \mathrm{H}, \mathrm{OH}), 5.08(\mathrm{~s}, 1 \mathrm{H}, \mathrm{OH})$, 4.42-4.38 (m, 1H, H-3'), 3.83-3.79 (m, 1H, H-4'), $3.62(\mathrm{dd}, J=$ 11.7, $4.5 \mathrm{~Hz}, 1 \mathrm{H}, \mathrm{H}-5 \mathrm{~b}^{\prime}$ ), 3.47 (br s, $\left.1 \mathrm{H}, \mathrm{H}-5 \mathrm{a}^{\prime}\right), 3.14(\mathrm{~s}, 1 \mathrm{H}$, $\mathrm{NCH}_{3}$ ), 3.10 (s, $1 \mathrm{H}, \mathrm{NCH}_{3}$ ), 3.10-2.95 (m, 1H, H-2b'), 2.01 (ddd, $J$ $\left.=9.2,6.5,2.6 \mathrm{~Hz}, \mathrm{H}-2 \mathrm{a}^{\prime}\right) ;{ }^{13} \mathrm{C} \mathrm{NMR}\left(125 \mathrm{MHz}, \mathrm{DMSO}-d_{6}\right) \delta 156.0$ $(\mathrm{C}=\mathrm{N}), 152.2$ (C8), 149.6 (C2), 148.9 (C6), 148.3 (C4), 111.7 (C5), $87.5\left(\mathrm{C}^{\prime}\right), 81.4\left(\mathrm{C}^{\prime}\right), 71.4\left(\mathrm{C}^{\prime}\right), 62.4\left(\mathrm{C}^{\prime}\right), 40.4\left(\mathrm{NCH}_{3}\right), 36.0$ $\left(\mathrm{C}^{\prime}\right), 34.3\left(\mathrm{NCH}_{3}\right)$; HRMS (ESI +$)$ : calcd for $\mathrm{C}_{13} \mathrm{H}_{18} \mathrm{~N}_{6} \mathrm{O}_{4}[\mathrm{M}+\mathrm{H}]^{+}$ 323.1462; found 323.1455 .

\section{7,8-Dihydro- $\mathrm{N}^{6}$-(dimethylaminomethylidene)-5' $-\mathrm{O}$ - dimethoxytrityl-8-oxo-2'-deoxy adenosine (28)}

The reaction of compound 27 (600 $\mathrm{mg}, 1.86 \mathrm{mmol}$ ) with 4,4'dimethoxytrityl chloride (693 $\mathrm{mg}, 2.05 \mathrm{mmol}$ ) in dry pyridine (60 $\mathrm{mL}$ ), was carried out as described for compound $\mathbf{1 7 a}$ and purified by flash column chromatography $\left(\mathrm{CH}_{2} \mathrm{CI}_{2} / \mathrm{MeOH} / \mathrm{TEA}\right.$, $95: 4: 1)$ to give $28(850 \mathrm{mg}, 73 \%)$ as a white foam. ${ }^{1} \mathrm{H}$ NMR $(600$ $\left.\mathrm{MHz}, \mathrm{DMSO}-d_{6}\right) \delta 8.70(\mathrm{~s}, 1 \mathrm{H}, \mathrm{HC}=\mathrm{N}), 8.04(\mathrm{~s}, 1 \mathrm{H}, \mathrm{H}-2), 7.36-$ 7.34 (m, 2H, Ar), 7.24-7.14 (m, 7H, Ar), 6.71-6.81 (m, 4H, Ar), 6.17 (dd, $J=7.2,6.2 \mathrm{~Hz}, 1 \mathrm{H}, \mathrm{H}-1^{\prime}$ ), 4.52 (br s, $\left.1 \mathrm{H}, \mathrm{H}-3^{\prime}\right), 3.94-3.88$ (m, $\left.1 \mathrm{H}, \mathrm{H}-4^{\prime}\right), 3.71\left(\mathrm{~s}, 3 \mathrm{H}, \mathrm{OCH}_{3}\right), 3.69$ (s, 3H, $\left.\mathrm{OCH}_{3}\right), 3.20-3.05$ $\left(\mathrm{m}, 9 \mathrm{H}, 2 \times \mathrm{NCH}_{3}, \mathrm{H}-5 \mathrm{a}^{\prime}, \mathrm{b}^{\prime}, \mathrm{H}-2 \mathrm{~b}^{\prime}\right), 2.09$ (ddd, $J=12.7,7.2,4.8$ $\left.\mathrm{Hz}, 1 \mathrm{H}, \mathrm{H}-2 \mathrm{a}^{\prime}\right) .{ }^{13} \mathrm{C}$ NMR (150 MHz, DMSO- $\left.d_{6}\right) \delta 157.9,157.8$, 155.8, 152.3, 149.7, 148.5, 145.1 (C2, C4, C8, C6, C=N, Ar), $135.8,135.6,129.7,129.5,128.9,127.6,127.6,127.41,126.4$, 113.0, 112.9, 112.7 (Ar), 111.7 (C5), $85.2\left(\mathrm{CPh}_{3}\right), 85.1\left(\mathrm{C}^{\prime}\right), 80.7$ $\left(\mathrm{C} 1^{\prime}\right), 71.0\left(\mathrm{C}^{\prime}\right), 64.2\left(\mathrm{C5}^{\prime}\right), 55.0,54.9\left(\mathrm{OCH}_{3}\right), 40.4\left(\mathrm{NCH}_{3}\right), 35.6$ $\left(\mathrm{C}^{\prime}\right), 34.3\left(\mathrm{NCH}_{3}\right)$; HRMS (ESI +$)$ : calcd for $\mathrm{C}_{34} \mathrm{H}_{36} \mathrm{~N}_{6} \mathrm{O}_{6}[\mathrm{M}+\mathrm{H}]^{+}$ 625.2768; found 625.2776.

7,8-Dihydro- $N^{6}$-(dimethylaminomethylidene) $-5^{\prime}-O$ dimethoxytrityl-8-oxo-2'-deoxyadenosine-3' -(2-cyanoethyl- $N, N$ diisopropyl)phosphoramidite (29)

The reaction of compound 28 (900 mg, $1.44 \mathrm{mmol}$ ), $1 \mathrm{M}$ bis(diisopropylamino)(2-cyanoethoxy)phosphine (2.88 mL, 2.88 $\mathrm{mmol}$ ) and $0.45 \mathrm{M}$ solution of $1 H$-tetrazole $(3.5 \mathrm{~mL}, 1.58 \mathrm{mmol})$ in $\mathrm{CH}_{2} \mathrm{Cl}_{2}(30 \mathrm{~mL})$ was carried out as described for compound 18a and purified by flash column chromatography ( $n$-hexane/ acetone/TEA, $49: 50: 1)$ to give $29(920 \mathrm{mg}, 77 \%)$ as a white foam. ${ }^{31} \mathrm{P}$ NMR (202 MHz, DMSO- $\left.d_{6}\right) \delta$ 147.4, 146.8. HRMS
(ESI+): calcd for $\mathrm{C}_{43} \mathrm{H}_{53} \mathrm{~N}_{8} \mathrm{O}_{7} \mathrm{P}[\mathrm{M}+\mathrm{H}]^{+}$825.3847; found 825.3842 .

\section{7,8-Dihydro- $N^{2}$-(dimethylaminomethylidene)-8-oxo-2'- deoxyguanosine (30)}

To a suspension of compound $4(1 \mathrm{~g}, 3.53 \mathrm{mmol})$ in $\mathrm{MeOH}$ (25 mL), $N, N$-dimethylformamide dimethyl acetal $(4.7 \mathrm{~mL}$, $35.3 \mathrm{mmol}$ ) was added. The reaction mixture was stirred at $25^{\circ} \mathrm{C}$ for $12 \mathrm{~h}$. The resulting precipitate was isolated, and was washed with $\mathrm{CH}_{2} \mathrm{Cl}_{2}$ to give 30 (600 mg, 50\%) as a white solid. ${ }^{1} \mathrm{H} \mathrm{NMR}$ $\left(600 \mathrm{MHz}, \mathrm{DMSO}-d_{6}\right) \delta 8.46(\mathrm{~s}, 1 \mathrm{H}, \mathrm{N}=\mathrm{CH}), 6.10(\mathrm{t}, J=7.3 \mathrm{~Hz}$, $\left.1 \mathrm{H}, \mathrm{H}-1^{\prime}\right), 5.16(\mathrm{~s}, 1 \mathrm{H}, \mathrm{OH}), 4.75(\mathrm{~s}, 1 \mathrm{H}, \mathrm{OH}), 4.39-4.33(\mathrm{~m}, 1 \mathrm{H}$, $\left.\mathrm{H}-3^{\prime}\right), 3.76-3.71\left(\mathrm{~m}, 1 \mathrm{H}, \mathrm{H}-4^{\prime}\right), 3.56(\mathrm{dd}, J=11.5,4.6 \mathrm{~Hz}, 1 \mathrm{H}, \mathrm{H}-$ $\left.5 \mathrm{~b}^{\prime}\right), 3.44\left(\mathrm{dd}, J=11.5,4.2 \mathrm{~Hz}, 1 \mathrm{H}, \mathrm{H}-5 \mathrm{a}^{\prime}\right), 3.12\left(\mathrm{~s}, 3 \mathrm{H}, \mathrm{NCH}_{3}\right.$ ), 3.00 (s, 3H, $\mathrm{NCH}_{3}$ ), 2.99-2.91 (m, $1 \mathrm{H}, \mathrm{H}-2 \mathrm{~b}^{\prime}$ ), 1.94 (ddd, $J=9.6$, 6.7, $\left.2.7 \mathrm{~Hz}, 1 \mathrm{H}, \mathrm{H}-2 \mathrm{a}^{\prime}\right) ;{ }^{13} \mathrm{C}$ NMR (150 MHz, DMSO- $\left.d_{6}\right) \delta 157.8$ $(\mathrm{C}=\mathrm{N}), 156.4$ (C6), 152.2 (C8), 151.7 (C2), 145.6 (C4), 102.2 (C5), $87.3\left(\mathrm{C}^{\prime}\right), 81.1\left(\mathrm{C}^{\prime}\right), 71.2\left(\mathrm{C}^{\prime}\right), 62.3\left(\mathrm{C5}^{\prime}\right), 40.7\left(\mathrm{NCH}_{3}\right), 36.0$ $\left(\mathrm{C}^{\prime}\right), 34.6\left(\mathrm{NCH}_{3}\right)$; HRMS (ESI+): calcd for $\mathrm{C}_{13} \mathrm{H}_{18} \mathrm{~N}_{6} \mathrm{O}_{5}[\mathrm{M}+\mathrm{Na}]^{+}$ 361.1231; found 361.1227 .

\section{7,8-Dihydro- $\mathrm{N}^{2}$-(dimethylaminomethylidene)-5'-O- dimethoxytrityl-8-oxo-2'-deoxy guanosine (31)}

The reaction of compound 30 (480 $\mathrm{mg}, 1.42 \mathrm{mmol}$ ) with 4,4'dimethoxytrityl chloride (528 mg, $1.56 \mathrm{mmol}$ ) in dry pyridine (60 $\mathrm{mL}$ ) was carried out as described for compound 17a and purified by flash column chromatography $\left(\mathrm{CH}_{2} \mathrm{CI}_{2} / \mathrm{MeOH} / \mathrm{TEA}\right.$, $97: 2: 1)$ to give $31(650 \mathrm{mg}, 71 \%)$ as a white foam. ${ }^{1} \mathrm{H}$ NMR $\left(600 \mathrm{MHz}, \mathrm{DMSO}-d_{6}\right) \delta 11.53(\mathrm{~s}, 1 \mathrm{H}, \mathrm{NH}), 10.82(\mathrm{~s}, 1 \mathrm{H}, \mathrm{NH}), 8.33$ $(\mathrm{s}, 1 \mathrm{H}, \mathrm{C}=\mathrm{N}), 7.36-7.31(\mathrm{~m}, 2 \mathrm{H}, \mathrm{Ar}), 7.25-7.15(\mathrm{~m}, 7 \mathrm{H}, \mathrm{Ar}), 6.72-$ $6.82(\mathrm{~m}, 4 \mathrm{H}, \mathrm{Ar}), 6.13\left(\mathrm{dd}, J=7.9,5.0 \mathrm{~Hz}, 1 \mathrm{H}, \mathrm{H}-1^{\prime}\right), 5.24(\mathrm{~d}, J=$ $4.9 \mathrm{~Hz}, 1 \mathrm{H}, \mathrm{OH}$ ), 4.46 (quin, $\left.J=4.9 \mathrm{~Hz}, 1 \mathrm{H}, \mathrm{H}-3^{\prime}\right), 3.81-3.85(\mathrm{~m}$, $\left.1 \mathrm{H}, \mathrm{H}-4^{\prime}\right), 3.72,3.71\left(\mathrm{OCH}_{3}\right), 3.20\left(\mathrm{dd}, J=9.9,7.5 \mathrm{~Hz}, 1 \mathrm{H}, \mathrm{H}-5 \mathrm{~b}^{\prime}\right)$, 3.07 (dd, $\left.J=9.9,3.3 \mathrm{~Hz}, 1 \mathrm{H}, \mathrm{H}-5 \mathrm{a}^{\prime}\right), 3.02,2.99\left(\mathrm{NCH}_{3}\right), 2.90-2.96$ $\left(\mathrm{m}, 1 \mathrm{H}, \mathrm{H}-2 \mathrm{~b}^{\prime}\right), 2.09$ (ddd, $\left.J=13.5,7.9,5.0 \mathrm{~Hz}, 1 \mathrm{H}, \mathrm{H}-2 \mathrm{a}^{\prime}\right) ;{ }^{13} \mathrm{C}$ NMR (150 MHz, DMSO- $\left.d_{6}\right) \delta$ 157.9, 157.8, 157.4, 156.0, 152.1, 151.6, 145.5, 145.1 (C6, C2, C=N, C8, C4, Ar), 135.8, 135.7, 129.6, 129.5, 127.7, 127.6, 126.4, 113.0, 112.9 (Ar), 112.7 (C5), $102.2\left(\mathrm{CPh}_{3}\right), 85.1\left(\mathrm{C}^{\prime}\right), 80.3\left(\mathrm{C}^{\prime}\right), 70.9\left(\mathrm{C}^{\prime}\right), 64.5\left(\mathrm{C5}^{\prime}\right), 54.9$, $54.9\left(\mathrm{OCH}_{3}\right), 40.6\left(\mathrm{NCH}_{3}\right), 36.4\left(\mathrm{C}^{\prime}\right), 34.6\left(\mathrm{NCH}_{3}\right)$; HRMS (ESI+): calcd for $\mathrm{C}_{34} \mathrm{H}_{36} \mathrm{~N}_{6} \mathrm{O}_{7}[\mathrm{M}+\mathrm{Na}]^{+}$663.2537; found 663.2537.

\section{7,8-Dihydro- $\mathrm{N}^{2}$-(dimethylaminomethylidene)-5'-O- dimethoxytrityl-8-oxo-2'-deoxyguanosine-3' -(2-cyanoethyl- $N, N$ - diisopropyl)phosphoramidite (32)}

The reaction of compound 31 (440 mg, $0.68 \mathrm{mmol}$ ), $1 \mathrm{M}$ bis(diisopropylamino)(2-cyanoethoxy)phosphine (1.37 mL, 1.37 $\mathrm{mmol}$ ) and $0.45 \mathrm{M}$ solution of $1 H$-tetrazole $(1.7 \mathrm{~mL}, 0.75 \mathrm{mmol})$ in $\mathrm{CH}_{2} \mathrm{Cl}_{2}(20 \mathrm{~mL})$ was carried out as described for compound 18a and purified by flash column chromatography ( $n$-hexane/ acetone/TEA, $49: 50: 1)$ to give $32(470 \mathrm{mg}, 81 \%)$ as a white foam. ${ }^{31} \mathrm{P}$ NMR (202 MHz, DMSO- $\left.d_{6}\right) \delta$ 147.8, 147.6. HRMS (ESI+): calcd for $\mathrm{C}_{43} \mathrm{H}_{53} \mathrm{~N}_{8} \mathrm{O}_{8} \mathrm{P}[\mathrm{M}+\mathrm{Na}]^{+}$863.3616; found 863.3620 


\section{Oligonucleotide synthesis}

Oligonucleotide assembly was performed with an Expedite DNA synthesizer (Applied Biosystems) by using the phosphoramidite approach. The oligomers were deprotected and cleaved from the solid support by treatment with aqueous ammonia (30\%) for $2 \mathrm{~h}$. After gel filtration on a NAP-25 column (Sephadex G25DNA grade; Pharmacia) with water as eluent, the crude mixture was analysed by using a Mono-Q HR 5/5 anion exchange column, after which purification was achieved by using a MonoQ HR 10/100 GL column (Pharmacia) with the following gradient system: $A=10 \mathrm{mM} \mathrm{NaClO}_{4}$ in $15 \% \mathrm{CH}_{3} \mathrm{CN}, \mathrm{pH} 7.4, B=$ $600 \mathrm{mM} \mathrm{NaClO}_{4}$ in $15 \% \mathrm{CH}_{3} \mathrm{CN}$, pH 7.4. The low-pressure liquid chromatography system consisted of a Merck-Hitachi L-6200A intelligent pump, a Mono-Q HR 10/100 GL column (Pharmacia), an Uvicord SII 2138 UV detector (Pharmacia-LKB) and a recorder. The product-containing fraction was desalted on a NAP-25 column and lyophilised. Analysis by mass spectrometry followed.

\section{UV melting experiments}

Oligomers were dissolved in a buffer solution containing $\mathrm{NaCl}$ $(0.1 \mathrm{M})$, potassium phosphate $(0.02 \mathrm{M}, \mathrm{pH} 7.5)$ and EDTA (0.1 $\mathrm{mM})$. The concentration was determined by measuring the absorbance in Milli-Q water at $260 \mathrm{~nm}$ at $80{ }^{\circ} \mathrm{C}$. The following extinction coefficients were used: $\mathrm{dA}, \varepsilon=15000 ; \mathrm{dT}, \varepsilon=8500$; C, $\varepsilon=7100 ; \mathrm{dG}, \varepsilon=12100 ; N^{8}$-8-aza-dG, $\varepsilon=2200 ; N^{8}$-8-aza-9deaza-dG, $\varepsilon=2500$; 8 - $\mathrm{NH}_{2}$-dI, $\varepsilon=6800$; 1 -Me-8- $\mathrm{NH}_{2}$-dI, $\varepsilon=$ 7600 ; d-isoC ${ }^{\mathrm{Me}}, \varepsilon=6300$; d-isoG, $\varepsilon=4600$; 8-Oxo-dI, $\varepsilon=7500$; 8Oxo-dA, $\varepsilon=11$ 100; 8-Oxo-dG, $\varepsilon=5900$. The concentration for each strand was $4 \mu \mathrm{M}$ in all experiments. Melting curves were determined with a Varian Cary 100 BIO spectrophotometer. Cuvettes were maintained at constant temperature by water circulation through the cuvette holder. The temperature of the solution was measured with a thermistor that was directly immersed in the cuvette. Temperature control and data acquisition were carried out automatically with an IBM-compatible computer by using Cary WinUV thermal application software. A quick heating and cooling cycle was carried out to allow proper annealing of both strands. The samples were then heated from 10 to $80{ }^{\circ} \mathrm{C}$ at a rate of $0.2{ }^{\circ} \mathrm{C} \mathrm{min}{ }^{-1}$, and were cooled again at the same speed. Melting temperatures were determined by plotting the first derivative of the absorbance as a function of temperature; data plotted were the average of two runs. Up and down curves showed identical $T_{\mathrm{m}}$ values.

\section{In vivo assay of XNA-oligonucleotides}

The oligomers were dissolved in MilliQ water to $100 \mathrm{mM}$. Before assay, they were diluted ten-fold in the same medium. Testing was performed with a gapped heteroduplex vector produced through the enzymatic digestion and PCR assisted denaturation and hybridization of the pAK1 and pAK2 plasmids. ${ }^{45} \mathrm{~A}$ mix of equimolar (25 ng each) purified pAK1 (NheI and NsiI cut) and purified pAK2 (two-fold EcoRI cut and dephosphorylated) was diluted into $10 \mathrm{mM}$ Tris- $\mathrm{HCl}$ (pH 7.5) with $100 \mathrm{mM} \mathrm{NaCl}$. The mixture was denatured at $95{ }^{\circ} \mathrm{C}$ for 5 min before cooling to ambient temperature over $2 \mathrm{~h}$, before water dialysis on $0.05 \mu \mathrm{M}$ nitrocellulose filters (Millipore) for $30 \mathrm{~min}$. The oligomers (0.02 pmol), as well as a positive d(CTAGCGCCGTGCCATGCA) and negative d(CTAGCGCCG $\cdots$ CATGCA) oligomer controls, were added separately to the dialyzed heteroduplex mixture diluted into $1 \times$ DNA ligase T4 reaction buffer (NEB) for $20 \mu \mathrm{L}$ per sample. The mixture was denatured at $85{ }^{\circ} \mathrm{C}$ as before. Ligation was performed by adding 5 U T4 DNA ligase (NEB) supplemented with $1 \mathrm{mM}$ ATP to the samples before overnight incubation $\left(16{ }^{\circ} \mathrm{C}\right)$. Ligated mixtures were dialyzed as before, and transformed by electroporation into electro-competent $E$. coli K12 ( $\Delta$ thyA:aadA). Incubation of the electroporated bacteria was made at $37^{\circ} \mathrm{C}$ for 1 hour, before plating $100 \mu \mathrm{L}$ of a serial dilution of the suspension onto Muller-Hinton ( $\mathrm{MH})$ media containing $100 \mu \mathrm{g} \mathrm{mL} \mathrm{m}^{-1}$ ampicillin (spreading the $10^{0}$ and $10^{-1}$ dilutions) and onto the same media supplemented additionally with $0.3 \mathrm{mM}$ thymidine $\left(10^{-3}\right.$ and $10^{-4}$ dilutions).

\section{In vivo assay of control DNA-oligonucleotides}

Control DNA oligomers were designed by modifying the 18-long standard oligomer to incorporate single changes at the codons tested. All DNA oligomers were ordered at Eurofins MWG and dissolved in MilliQ water to a concentration of $100 \mathrm{mM}$ before dilution ten-fold for testing. Assay of these oligos followed that of the XNA-oligonucleotides, following the same protocol as above.

\section{Data analysis and sequencing}

As before, ${ }^{8}$ the total numbers of thymidine-prototrophic colonies and ampicillin resistant colonies were taken from the plate counts, and the ratio of the former over the latter was calculated. Positive thymidine-prototrophic colonies were restreaked twice to $\mathrm{MH}$ ampicillin, before growth in $2 \mathrm{~mL}$ liquid cultures of the same medium. Plasmids were recovered by Miniprep (Qiagen) and the plasmids sequenced using an oligo for pAK1 d(AACAGTGGCGCGCCTGG).

\section{Generation of the $\Delta$ MutM strain}

The MutM gene was deleted from the E. coli K12 strain ( $\Delta$ thyA:aadA) through pKD46 meditation recombination, using a deletion construct containing flanking regions of the gene around an apramycin resistance cassette (aac(3)IV). Recombination was made by the published procedure. ${ }^{54}$ Deletion was confirmed by external primers through colony-PCR.

\section{Acknowledgements}

We thank Luc Baudemprez for technical assistance and Chantal Biernaux for editorial help. The research leading to these results has received funding from the European Research Council under the European Union's Seventh Framework Programme (FP7/2007-2013)/ERC Grant agreement no. ERC-2012ADG_20120216/320683, from FWO Vlaanderen, Belgium (G078014N) and from the KU Leuven Research Council (OT/ 1414/128). Mass spectrometry was made possible by the support 
of the Hercules Foundation of the Flemish Government (grant 20100225-7).

\section{Notes and references}

1 S. A. Benner, Acc. Chem. Res., 2004, 37, 784-797.

2 H. Liu, J. Gao, S. R. Lynch, Y. D. Saito, L. Maynard and E. T. Kool, Science, 2003, 302, 868-871.

3 I. Hirao, M. Kimoto and R. Yamashige, Acc. Chem. Res., 2012, 45, 2055-2065.

4 D. A. Malyshev, K. Dhami, H. T. Quach, T. Lavergne, P. Ordoukhanian, A. Torkamani and F. E. Romesberg, Proc. Natl. Acad. Sci. U. S. A., 2012, 109, 12005-12010.

5 R. Yamashige, M. Kimoto, Y. Takezawa, A. Sato, T. Mitsui, S. Yokoyama and I. Hirao, Nucleic Acids Res., 2012, 40, 2793-2806.

6 J. C. Chaput, H. Yu and S. Zhang, Chem. Biol., 2012, 19, 13601371.

7 D. A. Malyshev, K. Dhami, T. Lavergne, T. Chen, N. Dai, J. M. Foster, I. R. Corrêa and F. E. Romesberg, Nature, 2014, 509, 385-388.

8 O. Bande, R. Abu El Asrar, D. Braddick, S. Dumbre, V. Pezo, G. Schepers, V. B. Pinheiro, E. Lescrinier, P. Holliger, P. Marlière and P. Herdewijn, Chem.-Eur. J., 2015, 21, 5009-5022.

9 S. C. Johnson, C. B. Sherrill, D. J. Marshall, M. J. Moser and J. R. Prudent, Nucleic Acids Res., 2004, 32, 1937-1941.

10 C. Y. Switzer, S. E. Moroney and S. A. Benner, Biochemistry, 1993, 32, 10489-10496.

11 A. K. Ogawa, Y. Wu, M. Berger, P. G. Schultz and F. E. Romesberg, J. Am. Chem. Soc., 2000, 122, 8803-8804.

12 S. A. Benner and A. M. Sismour, Nat. Rev. Genet., 2005, 6, 533-543.

13 E. T. Kool, Acc. Chem. Res., 2002, 35, 936-943.

14 J. S. Koh and P. B. Dervan, J. Am. Chem. Soc., 1992, 114, 14701478.

15 Z. Kazimierczuk, U. Binding and F. Seela, Helv. Chim. Acta, 1989, 72, 1527-1536.

16 J. He and F. Seela, Org. Biomol. Chem., 2003, 1, 1873-1883.

17 F. Seela, M. Zulauf and H. Debelak, Helv. Chim. Acta, 2000, 83, 1437-1453.

18 J. He and F. Seela, Helv. Chim. Acta, 2002, 85, 1340-1354.

19 F. Seela and H. Debelak, Nucleic Acids Res., 2000, 28, 32243232.

20 F. Seela and R. Kröschel, Org. Biomol. Chem., 2003, 1, 39003908.

21 F. Seela and S. Lampe, Helv. Chim. Acta, 1994, 77, 1003-1017.

22 F. Seela and S. Lampe, Helv. Chim. Acta, 1993, 76, 2388-2397.

23 R. B. Meyer, G. Revankar, P. D. Cook, K. Ehler, M. Schweizer and R. Robins, J. Heterocycl. Chem., 1980, 17, 159-169.

24 E. Cubero, A. Avinó, B. G. de la Torre, M. Frieden, R. Eritja, F. J. Luque, C. González and M. Orozco, J. Am. Chem. Soc., 2002, 124, 3133-3142.

25 E. Cubero, R. Güimil-García, F. J. Luque, R. Eritja and M. Orozco, Nucleic Acids Res., 2001, 29, 2522-2534.

26 R. Eritja and R. Garcia, US Pat., US 2003/0135040 A 1, 2003.

27 S. Uesugi and M. Ikehara, J. Am. Chem. Soc., 1977, 99, 32503253.
28 E. N. Nikolova, H. Zhou, F. L. Gottardo, H. S. Alvey, I. J. Kimsey and H. M. Al-Hashimi, Biopolymers, 2013, 99, 955-968.

29 N. Oka and M. M. Greenberg, Nucleic Acids Res., 2005, 33, 1637-1643.

30 V. Bodepudi, C. R. Iden and F. Johnson, Nucleosides Nucleotides, 1991, 10, 755-761.

31 V. Bodepudi, S. Shibutani and F. Johnson, Chem. Res. Toxicol., 1992, 5, 608-617.

32 S. Koizume, H. Kamiya, H. Inoue and E. Ohtsuka, Nucleosides, Nucleotides Nucleic Acids, 1994, 13, 1517-1534.

33 Y. Wang and Y. Wang, Chem. Res. Toxicol., 2006, 19, 837-843.

34 S. Shibutani, M. Takeshita and A. P. Grollman, Nature, 1991, 349, 431-434.

35 A. Guy, A. M. Duplaa, P. Harel and R. Téoule, Helv. Chim. Acta, 1988, 71, 1566-1572.

36 H. Komatsu, T. Ichikawa, M. Nakai and H. Takaku, Nucleosides Nucleotides, 1992, 11, 85-95.

37 L. Petraccone, I. Duro, E. Erra, A. Randazzo, A. Virno and C. Giancola, Nucleosides, Nucleotides Nucleic Acids, 2007, 26, 675-679.

38 V. Esposito, A. Randazzo, A. Virgilio, L. Cozzuto and L. Mayol, Nucleosides, Nucleotides Nucleic Acids, 2005, 24, 783-788.

39 M. Kouchakdjian, V. Bodepudi, S. Shibutani, M. Eisenberg, F. Johnson, A. P. Grollman and D. J. Patel, Biochemistry, 1991, 30, 1403-1412.

40 K. E. McAuley-Hecht, G. A. Leonard, N. J. Gibson, J. B. Thomson, W. P. Watson, W. N. Hunter and T. Brown, Biochemistry, 1994, 33, 10266-10270.

41 W. A. Beard, V. K. Batra and S. H. Wilson, Mutat. Res., Genet. Toxicol. Environ. Mutagen., 2010, 703, 18-23.

42 M. L. Wood, A. Esteve, M. L. Morningstar, G. M. Kuziemko and J. M. Essigmann, Nucleic Acids Res., 1992, 20, 6023-6032.

43 A. P. Breen and J. A. Murphy, Free Radical Biol. Med., 1995, 18, 1033-1077.

44 M. L. Michaels, L. Pham, C. Cruz and J. H. Miller, Nucleic Acids Res., 1991, 19, 3629-3632.

45 J. Tchou, H. Kasai, S. Shibutani, M. H. Chung, J. Laval, A. P. Grollman and S. Nishimura, Proc. Natl. Acad. Sci. U. S. A., 1991, 88, 4690-4694.

46 R. D. Elliott and J. A. Montgomery, J. Med. Chem., 1976, 19, 1186-1191.

47 J. Davoll, J. Chem. Soc., 1958, 1593-1599.

48 L. B. Townsend, Chemistry of nucleosides and nucleotides, Plenum Press, New York, 1994.

49 M. C. Buff, F. Schäfer, B. Wulffen, J. Müller, B. Pötzsch, A. Heckel and G. Mayer, Nucleic Acids Res., 2010, 1148.

50 C. Chatgilialoglu, M. L. Navacchia and A. Postigo, Tetrahedron Lett., 2006, 47, 711-714.

51 A. Kannan and C. J. Burrows, J. Org. Chem., 2010, 76, 720-723. 52 S. Pochet, P. A. Kaminski, A. van Aerschot, P. Herdewijn and P. Marlière, C. R. Biol., 2003, 326, 1175-1184.

53 V. Pezo, F. W. Liu, M. Abramov, M. Froeyen, P. Herdewijn and P. Marlière, Angew. Chem., Int. Ed. Engl., 2013, 52, 8139-8143.

54 K. A. Datsenko and B. L. Wanner, Proc. Natl. Acad. Sci. U. S. A., 2000, 97, 6640-6645. 